\title{
Longitudinal Accumulation of Cerebral Microhemorrhages in Dominantly Inherited Alzheimer Disease
}

Nelly Joseph-Mathurin, PhD, Guoqiao Wang, PhD, Kejal Kantarci, MD, MS, Clifford R. Jack, Jr., MD, Eric McDade, DO, Jason Hassenstab, PhD, Tyler M. Blazey, PhD, Brian A. Gordon, PhD, Yi Su, PhD, Gengsheng Chen, PhD, Parinaz Massoumzadeh, PhD, Russ C. Hornbeck, MSc, Ricardo F. Allegri, MD, PhD, Beau M. Ances, MD, PhD, Sarah B. Berman, MD, PhD, Adam M. Brickman, PhD, William S. Brooks, MB BS, David M. Cash, PhD, Jasmeer P. Chhatwal, MD, PhD, Helena C. Chui, MD, Stephen Correia, PhD, Carlos Cruchaga, PhD, Martin R. Farlow, MD, Nick C. Fox, MD, Michael Fulham, MD, Bernardino Ghetti, MD, Neill R. Graff-Radford, MD, Keith A. Johnson, MD, Celeste M. Karch, PhD, Christoph Laske, MD, Athene K.W. Lee, PhD, Johannes Levin, MD, PhD, Colin L. Masters, MD, James M. Noble, MD, MS, Antoinette O'Connor, MRCPI, Richard J. Perrin, MD, PhD, Gregory M. Preboske, MSc, John M. Ringman, MD, Christopher C. Rowe, MD, Stephen Salloway, MD, MS, Andrew J. Saykin, PsyD, Peter R. Schofield, PhD, DSc, Hiroyuki Shimada, MD, PhD, Mikio Shoji, MD, PhD, Kazushi Suzuki, MD, PhD, Victor L. Villemagne, MD,

Chengjie Xiong, PhD, Igor Yakushev, MD, John C. Morris, MD, Randall J. Bateman, MD, and

Tammie L.S. Benzinger, MD, PhD, on behalf of the Dominantly Inherited Alzheimer Network

Neurology ${ }^{\circledR}$ 2021;96:e1632-e1645. doi:10.1212/WNL.0000000000011542

\section{Abstract}

\section{Objective}

To investigate the inherent clinical risks associated with the presence of cerebral microhemorrhages (CMHs) or cerebral microbleeds and characterize individuals at high risk for developing hemorrhagic amyloid-related imaging abnormality (ARIA-H), we longitudinally evaluated families with dominantly inherited Alzheimer disease (DIAD).

\section{Methods}

Mutation carriers $(n=310)$ and noncarriers $(n=201)$ underwent neuroimaging, including gradient echo MRI sequences to detect CMHs, and neuropsychological and clinical assessments. Cross-sectional and longitudinal analyses evaluated relationships between CMHs and neuroimaging and clinical markers of disease.

\section{Results}

Three percent of noncarriers and 8\% of carriers developed CMHs primarily located in lobar areas. Carriers with $\mathrm{CMHs}$ were older, had higher diastolic blood pressure and Hachinski ischemic scores, and more clinical, cognitive, and motor impairments than those without CMHs. APOE \&4 status was not associated with the prevalence or incidence of CMHs.

\author{
Correspondence \\ Dr. Benzinger \\ benzingert@wustl.edu
}

\section{MORE ONLINE}

๑ CME Course

NPub.org/cmelist

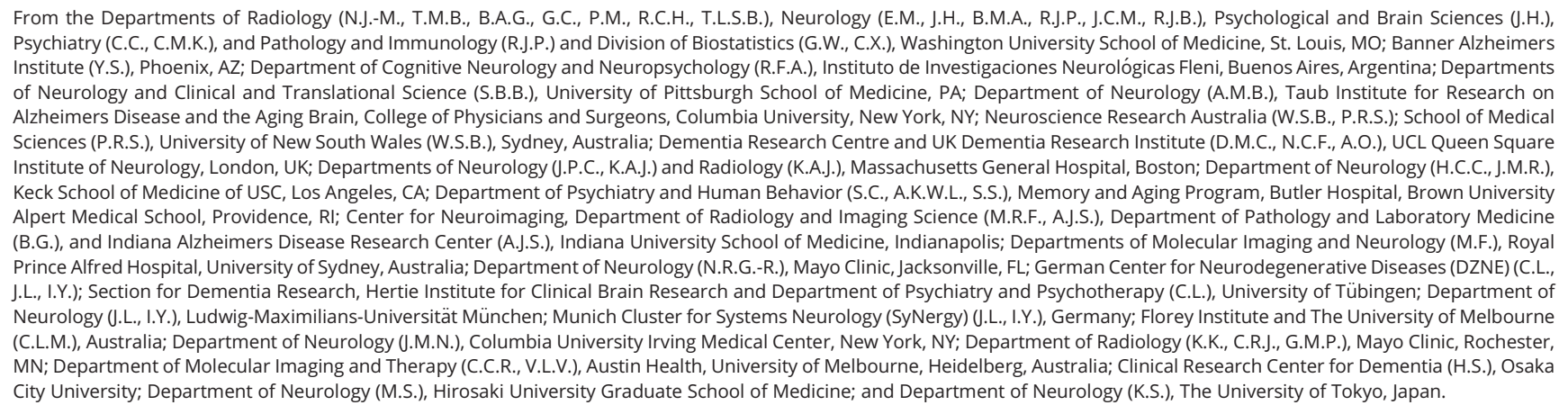

Go to Neurology.org/N for full disclosures. Funding information and disclosures deemed relevant by the authors, if any, are provided at the end of the article. 


\section{Glossary}

$\mathbf{A} \beta=\beta$-amyloid $\mathbf{A D}=$ Alzheimer disease; ARIA-E = edema type amyloid-related imaging abnormalities; ARIA-H = hemorrhagic amyloid-related imaging abnormalities; CAA = cerebral amyloid angiopathy; CDR = Clinical Dementia Rating; CDR-SB = Clinical Dementia Rating Sum of Boxes; CI = confidence interval; CMH = cerebral microhemorrhage; DIAD = dominantly inherited Alzheimer disease; DIAN = Dominantly Inherited Alzheimer Network; EYO = estimated years to symptom onset; FLAIR = fluid-attenuated inversion recovery; GRE = gradient recalled echo; HSD = honestly significant difference; $\mathbf{L M E}=$ linear mixed effects; $\mathbf{M A P}=$ mean arterial pressure; $\mathbf{O R}=$ odds ratio; $\mathbf{S W I}$ = susceptibility-weighted image; TE = echo time; $\mathbf{T R}=$ repetition time; $\mathbf{W M H}=$ white matter hyperintensity.

Prevalent or incident CMHs predicted faster change in Clinical Dementia Rating although not composite cognitive measure, cortical thickness, hippocampal volume, or white matter lesions. Critically, the presence of 2 or more CMHs was associated with a significant risk for development of additional CMHs over time ( $8.95 \pm 10.04$ per year).

\section{Conclusion}

Our study highlights factors associated with the development of CMHs in individuals with DIAD. CMHs are a part of the underlying disease process in DIAD and are significantly associated with dementia. This highlights that in participants in treatment trials exposed to drugs, which carry the risk of ARIA-H as a complication, it may be challenging to separate natural incidence of CMHs from drug-related CMHs.

Cerebral microhemorrhages (CMHs) or microbleeds, small bleeds in the brain, are commonly observed in older adults, particularly in those with dementia. ${ }^{1}$ These lesions are commonly related to hypertension, ${ }^{2}$ vascular $\beta$-amyloid (A $\beta$ ) related to Alzheimer disease $(\mathrm{AD})$ or cerebral amyloid angiopathy $(\mathrm{CAA}),{ }^{3}$ or $\mathrm{A} \beta$-modifying therapies currently in $\mathrm{AD}$ clinical trials ${ }^{4}$ as part of the constellation of hemorrhagic amyloid-related imaging abnormalities (ARIA-H). The presence of CMHs at baseline predicts future additional $\mathrm{CMHs}$ in both the general population ${ }^{3}$ and in $\mathrm{AD} .^{5}$ Therefore, during trials of $A \beta$-modifying therapies, the Food and Drug Administration recommends monitoring for $\mathrm{CMHs}$ and excluding participants with 5 or more $\mathrm{CMHs}{ }^{6}$

Because older participants often have mixed pathologies, it can be difficult to discriminate or identify which of these 3 factors is responsible for $\mathrm{CMHs}$, particularly in treatment trials. Evaluating a young cohort, such as individuals with dominantly inherited $\mathrm{AD}$ (DIAD), ${ }^{7,8}$ with relatively normal blood pressure and not on treatment may help characterize the natural history of $\mathrm{CMHs}$ uniquely related to $\mathrm{AD}$. This may provide a better understanding of the implications of CMHs when observed in individuals with DIAD in treatment trials as well as potentially help evaluate other $\mathrm{AD}$ cohorts.

Here, we report results from the Dominantly Inherited Alzheimer Network (DIAN) observational study, ${ }^{9}$ in which participants are assessed for ARIA-H and followed longitudinally with the aim of defining the clinical risks related to CMHs.

\section{Methods}

\section{Participants}

We evaluated 511 participants from 19 DIAN sites using standardized clinical, neuropsychological, and imaging assessments according to DIAN study protocols. ${ }^{9}$ Of the 534 participants with data that passed strict quality control procedures as part of the 14th DIAN Data Freeze (January 2009-December 2019), we selected data based on the availability of MRI and radiology reads from Mayo Clinic. APP, PSEN1, and PSEN2 mutation carriers ( $\mathrm{n}=310$, including 109 symptomatic) and noncarriers $(\mathrm{n}=201)$ underwent clinical assessments, neuropsychological testing, and neuroimaging. A subset of 218 carriers, including 76 symptomatic and 127 noncarriers, had at least one follow-up visit and were evaluated longitudinally. These participants had similar clinical characteristics as those without follow-up.

\section{Standard Protocol Approvals, Registrations, and Patient Consents}

Each DIAN site received approval from its institutional review board and its institutional or regional ethical standards committee on human experimentation. All participants or their caregivers provided written informed consent approved by their local institutional review board.

\section{Clinical Assessment}

The protocol used for the clinical assessment is as previously described..$^{10}$ Clinical Dementia Rating (CDR) evaluated the presence ( $\mathrm{CDR}>0$, symptomatic) or absence (CDR 0 , asymptomatic) of dementia. ${ }^{11}$ The CDR Sum of Boxes (CDR-SB) is a total score of all subcategories of the CDR assessment and was used as a continuous measure. ${ }^{11}$ The estimated years to symptom onset (EYO) was defined as the participant's age at each assessment minus the estimated age at symptom onset for their specific mutation. ${ }^{7}$ Other clinical and vascular-related measures were assessed, including diastolic and systolic blood pressure and mean arterial pressure (MAP). Conditions of hypertension, stroke, hypercholesterolemia, and diabetes were clinically diagnosed. The Hachinski Ischemic Score, ${ }^{12}$ taking into account any history of 
hypertension and history of stroke, was also assessed. Motor impairment, including assessment of gait and tremor, were also evaluated. An abnormal gait was reported when the participant was unsteady, shuffled, had little or no arm swing, dragged a foot, or had a change in gait not due to injury or arthritis. Clinicians who performed the assessments were not explicitly aware of the mutation status of participants.

\section{Neuropsychological Testing}

Participants underwent a comprehensive battery of neuropsychological tests at each visit, as described previously. ${ }^{13}$ The battery included measures of global cognition, episodic memory, executive function, attention, processing speed, semantic memory, and language. To minimize the number of statistical comparisons, a cognitive composite measure similar to the one used as an endpoint in the DIAN Trials Unit ${ }^{14}$ and in the $\mathrm{A} 4$ trial $^{15}$ was included in the analyses. The cognitive composite consisted of the Mini-Mental State Examination global score, Digit-Symbol Substitution from the Wechsler Adult Intelligence Scale-Revised, Logical Memory delayed recall from the Wechsler Memory Scale-Revised, and the delayed recall of the DIAN Word List Test. Scores from each test were transformed to $z$ scores using the mean and SD of a relatively healthy cohort that is at least 15 years before estimated age at symptom onset and then averaged to form the cognitive composite score. ${ }^{16}$

\section{Image Acquisition Protocol}

Standardized procedures and protocols, concordant with the Alzheimer Disease Neuroimaging Initiative group, were used at the different DIAN sites to ensure consistency in data collection (adni-info.org). The scanner parameters and image quality were reviewed by the Mayo Clinic in Rochester as previously described. ${ }^{17}$ During baseline and follow-up MRI sessions, all participants underwent on $3 \mathrm{~T}$ scanners a magnetization-prepared rapid acquisition with gradient echo (resolution $1.0 \times 1.0 \times 1.2 \mathrm{~mm}^{3}$, repetition time [TR] 2,300 $\mathrm{ms}$, echo time [TE] $2.95 \mathrm{~ms})$, a fluid-attenuated inversion recovery (FLAIR) (resolution $0.86 \times 0.86 \times 5.0 \mathrm{~mm}^{3}$, TR 9,000 ms, TE $90 \mathrm{~ms}$ ), and a gradient recalled echo (GRE)based sequence, either a T2*-GRE (resolution $0.8 \times 0.8 \times$ $4 \mathrm{~mm}^{3}$, TR $650 \mathrm{~ms}$, TE $20 \mathrm{~ms}$ ) or a susceptibility-weighted image (SWI) (resolution $0.7 \times 0.7 \times 2 \mathrm{~mm}^{3}$, TR $28 \mathrm{~ms}$, TE 20 $\mathrm{ms}$ ). At baseline visit, 240 participants had T2*-GRE and 234 had SWI sequences. Longitudinal scans were coregistered and reviewed concurrently. Due to harmonization among sites and vendors, some participants switched sequence at followup from SWI to T2*-GRE $(\mathrm{n}=153)$. The T2*-GRE was tailored to be sensitive to small $\mathrm{CMHs}$ with an acquisition time of $\sim 2.5$ minutes.

\section{Image Processing and Analyses}

CMHs, macrohemorrhages, and superficial siderosis were identified on either T2*-GRE or SWI and confirmed by coauthors K.K. and C.R.J. using the same methodology for cross-sectional and longitudinal evaluation previously described by Kantarci et al. ${ }^{18}$ Lesions $\leq 10 \mathrm{~mm}$ that were dissociable from small vessels were counted as definite CMHs. Macrohemorrhages were larger hemorrhagic lesions visible on multiple slices and superficial siderosis was defined by visible signal abnormalities along the pia. The $\mathrm{CMH}$ location was reported as deep (basal ganglia, brainstem, thalamus), lobar (supratentorial cortico-subcortical areas of the frontal, parietal, temporal, and occipital lobes), or cerebellar. All findings reported from visual inspection of the images passed quality control from the Mayo Clinic. White matter hyperintensity (WMH) volumes were extracted from FLAIR images using the lesion segmentation toolbox in SPM8. ${ }^{19}$ The cortical thickness of precuneus and inferior parietal, regions known to be highly affected in DIAD, ${ }^{20,21}$ and the hippocampal volume were measured using FreeSurfer software (surfer.nmr.mgh.harvard.edu/).

\section{Statistical Analysis}

Demographic, clinical, and vascular-related measures were compared among noncarriers, carriers without $\mathrm{CMHs}$, and carriers with CMHs for the cross-sectional cohort and among noncarriers, carriers without change in $\mathrm{CMH}$ counts, and carriers with increase in $\mathrm{CMH}$ counts at follow-up for the longitudinal subset. The mutation carrier group with $\mathrm{CMHs}$ was older and more advanced in expected disease stage (analysis of variance and Tukey honestly significant difference [HSD $]$ post hoc tests). Thus, age and family age at onset were included as covariates in analysis of covariance/Tukey HSD and logistic regression/Wald $\chi^{2}$ tests for group comparisons of continuous and dichotomous variables, respectively.

Cross-sectional analyses evaluated the prevalence and location of CMHs in carriers and noncarriers. Multivariable logistic regression analyses were used to evaluate factors associated with the prevalence of $\mathrm{CMHs}$ (dichotomized as yes vs no) in noncarriers and carriers with the stepwise selection method. The goodness of model fit was evaluated using the Hosmer and Lemeshow test. ${ }^{22}$ Because of the relatively small number of events, the penalized maximum likelihood method was used to estimate the parameters and profile likelihood confidence intervals (CIs) were reported for odds ratios (ORs). ${ }^{22}$ Fisher exact tests investigated effect of mutation types (PSEN1/PSEN2/APP) and subtypes (PSEN1 mutation before/after codon 200 and APP-Dutch/APP-non-Dutch) on prevalent or incident CMHs.

To determine whether the number of $\mathrm{CMHs}$ at baseline influenced the rate of incident CMHs in carriers, the severity of $\mathrm{CMH}$ finding was categorized as follows: no (0 CMHs), mild (1 CMH), moderate (2-4 CMHs), and severe (more than $4 \mathrm{CMHs}$ ). Similar categorization was used previously to evaluate association of $\mathrm{CMHs}$ with cognitive decline. ${ }^{23}$ Generalized linear mixed effects (LME) models were used to estimate the rate of change in CMHs for asymptomatic carriers and symptomatic carriers and to evaluate whether the presence of CMHs at baseline (dichotomized as yes vs no), its increase (dichotomized as yes vs no), or the number of CMHs at baseline, respectively, were associated with the longitudinal 
Table 1 Demographics of Cross-Sectional Data

\begin{tabular}{|c|c|c|c|c|}
\hline \multirow[b]{2}{*}{ Characteristics } & \multirow[b]{2}{*}{ NC } & \multicolumn{2}{|l|}{ MC } & \multirow[b]{2}{*}{$p$ Value } \\
\hline & & No CMH & $\mathrm{CMH}+$ & \\
\hline N (PSEN1/PSEN2/APP) & 201 & $284(212 / 23 / 49)$ & $26(20 / 1 / 5)$ & - \\
\hline PSEN1 post-c200, n (\% PSEN1) & - & $135(64)$ & $15(75)$ & - \\
\hline APP Dutch, $\mathrm{n}(\%$ APP $)$ & - & $9(18)$ & $1(20)$ & - \\
\hline Age, y & $37.5(11.2)$ & $37.1(10.6)$ & $46.7(10.5)^{\star}, \dagger$ & $<0.0001$ \\
\hline EYO, y & $-10.2(11.6)$ & $-8.8(11.0)$ & $1.6(8.3)^{*}, \dagger$ & $<0.0001$ \\
\hline Family mutation age at onset, y & $48.3(6.8)$ & $46.4(7.8) \ddagger$ & $45.6(6.6)$ & $<0.05$ \\
\hline Education (3 missing) & $14.3(2.9)$ & $14.3(3.1)$ & $13.6(3.0)$ & 0.08 \\
\hline Male & $86(42.8)$ & $118(41.5)$ & $17(65.4)$ & 0.06 \\
\hline APOE ع4+ & $61(30.3)$ & $86(30.3)$ & $6(23.1)$ & 0.74 \\
\hline Cases with diabetes ${ }^{\mathrm{a}}$ (1 missing) & $7(3.5)$ & $3(1.1)$ & $2(7.7)$ & $0.17^{a}$ \\
\hline Cases of hypercholesterolemia ${ }^{a}$ (10 missing) & $25(12.7)$ & $37(13.3)$ & $4(15.4)$ & $0.65^{a}$ \\
\hline Cases with hypertension ${ }^{a}$ & $24(11.9)$ & $14(4.9) \ddagger$ & $5(19.2)$ & $<0.05^{\mathrm{a}}$ \\
\hline Diastolic blood pressure, ${ }^{a} \mathrm{~mm} \mathrm{Hg}$ & $76.4(10.5)$ & $74.5(9.6)$ & $81.7(9.3) \S$ & $<0.005^{\mathrm{a}}$ \\
\hline Systolic blood pressure, ${ }^{a} \mathrm{~mm} \mathrm{Hg}$ & $123.0(17.0)$ & $121.1(13.3)$ & $129.4(12.7)$ & $0.068^{\mathrm{a}}$ \\
\hline Mean arterial pressure, ${ }^{\mathrm{a}} \mathrm{mm} \mathrm{Hg}$ & $91.9(11.7)$ & $90.0(9.8)$ & $97.6(9.3) \uparrow$ & $<0.005^{\mathrm{a}}$ \\
\hline CDR-Global $>0^{b}$ & $12(6.0)$ & $89(31.3)^{*}$ & $20(76.9)^{\star}$ & $<0.0001^{\mathrm{b}}$ \\
\hline CDR-SB ${ }^{b}$ & $0.05(0.18)$ & $1.19(2.91)^{*}$ & $2.75(2.37)^{*}$ & $<0.0001^{\mathrm{b}}$ \\
\hline Cognitive composite $^{\mathrm{b}}$ (39 missing) & $0.01(0.63)$ & $-0.44(1.00)^{\star}$ & $-1.51(1.02)^{*}, \S$ & $<0.0001^{\mathrm{b}}$ \\
\hline Hachinski Ischemia Score ${ }^{a}$ (1 missing) & $0.20(0.52)$ & $0.25(0.70)$ & $1.15(2.15)^{\star}, \dagger$ & $<0.0001^{a}$ \\
\hline Abnormal gait $^{a}$ & $5(2.5)$ & $15(5.3)$ & $6(23.1)^{\star *}, 9$ & $<0.05^{a}$ \\
\hline Tremor $^{a}$ & $10(5.0)$ & $17(6.0)$ & $1(3.8)$ & $0.61^{\mathrm{a}}$ \\
\hline WMH volume, ${ }^{a} \mathrm{~mm}^{3}$ (17 missing) & $2,504.7(3,479.5)$ & $4,895.9(9,775.9) \ddagger$ & $21,568.1(32,725.2)^{*}, \dagger$ & $<0.0001^{a}$ \\
\hline Precuneus thickness, ${ }^{a}$ mm (18 missing) & $2.38(0.12)$ & $2.30(0.21)^{*}$ & $2.12(0.23)^{\star}, \boldsymbol{\Phi}$ & $<0.0001^{a}$ \\
\hline Hippocampal volume, ${ }^{a} \mathrm{~mm}^{3}$ (18 missing) & $8,816.1(643.2)$ & $8,456.5(1,139.8)^{*}$ & $7,557.8(1,564.2)^{\star}, \boldsymbol{\Upsilon}$ & $<0.0001^{\mathrm{a}}$ \\
\hline CMH prevalence ${ }^{c}$ & $6(3.0)$ & $26(8.4)$ & & $<0.05^{c}$ \\
\hline CMHs baseline, ${ }^{\mathrm{C}}$ median (lower - upper quartile) & $0.0(0.0-0.0)$ & $0.0(0.0-0.0)$ & & $0.16^{c}$ \\
\hline 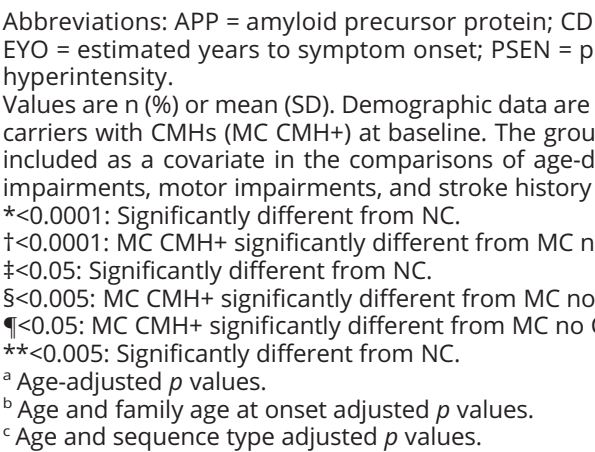 & $\begin{array}{l}\text { al = Clinical Demen } \\
\text { in; PSEN1 post-c20 } \\
\text { for noncarriers (NC } \\
\text { similar proportion } \\
\text { ent demographic v } \\
\text { eline. }\end{array}$ & $\begin{array}{l}\text { ing global score; } C D \\
\text { senilin-1 mutation } \\
\text { hutation carriers with } \\
\text { en and APOE \&4+ bu } \\
\text { s }(\mathrm{a}, \mathrm{b}, \mathrm{c}, \mathrm{c}) \text {. The MC CM! }\end{array}$ & $\begin{array}{l}\text { Clinical Dementia Ratir } \\
\text { n after codon 200; WM } \\
\text { rebral microbleeds (MC } \\
\text { ic CMH+ group was old } \\
\text { up was particularly affe }\end{array}$ & $\begin{array}{l}\text { of Boxes; } \\
\text { ite matter } \\
\text {-1), and for } \\
\text { s, age was } \\
\text { cognitive }\end{array}$ \\
\hline
\end{tabular}

change in cortical thickness, hippocampal volume, WMH volumes, $\mathrm{CDR}-\mathrm{SB}$, and the cognitive composite among carriers. ${ }^{24}$ To discount potential effects of pathology in Dutch mutation carriers, all analyses were also run excluding this group. The type of scanner sequence (T2*-GRE, SWI, and SWI to T2*-GRE) was controlled for in the longitudinal 
Table 2 Demographics of Longitudinal Data

\begin{tabular}{|c|c|c|c|c|}
\hline \multirow[b]{2}{*}{ Characteristics } & \multirow[b]{2}{*}{ NC } & \multicolumn{2}{|l|}{ MC } & \multirow[b]{2}{*}{$p$ Value } \\
\hline & & No change in $\mathrm{CMH}$ & Increase in $\mathrm{CMH}$ & \\
\hline $\mathrm{N}$ (PSEN1/PSEN2/APP) & 127 & $195(143 / 13 / 39)$ & $23(15 / 0 / 8)$ & - \\
\hline PSEN1 post-c200, n (\% PSEN1) & - & $90(63)$ & $11(73)$ & - \\
\hline APP Dutch, n (\% APP) & - & $5(13)$ & $5(63)$ & - \\
\hline Baseline age, y & $36.8(10.2)$ & $37.0(10.7)$ & $47.0(7.5)^{*}, \dagger$ & $<0.0001$ \\
\hline Visit gaps, y & $1.4(0.6)$ & $1.2(0.6)^{\star \star}$ & $0.9(0.3)^{\star}, \boldsymbol{\Phi}$ & $<0.0001$ \\
\hline Baseline EYO, y & $-10.9(10.5)$ & $-9.1(11.0)$ & $1.6(4.9)^{*}, \dagger$ & $<0.0001$ \\
\hline Family mutation age at onset, y & $48.1(6.0)$ & $46.6(7.4)$ & $45.7(6.5)$ & 0.11 \\
\hline Education & $15.1(2.7)$ & $14.3(3.1)$ & $14.6(2.7)$ & 0.06 \\
\hline Male & $52(40.9)$ & $83(42.6)$ & $12(52.2)$ & 0.61 \\
\hline APOE $\varepsilon 4+$ & $35(27.6)$ & $62(31.8)$ & $5(21.7)$ & 0.50 \\
\hline Cases with diabetes ${ }^{a}$ ( 1 missing) & $2(1.6)$ & $1(0.6)$ & $0(0)$ & $0.65^{a}$ \\
\hline Cases of hypercholesterolemia ${ }^{a}$ (10 missing) & $11(8.9)$ & $26(13.8)$ & $4(17.4)$ & $0.44^{a}$ \\
\hline Cases with hypertension ${ }^{a}$ & $12(9.4)$ & $8(4.1)$ & $3(13.0)$ & $0.12^{\mathrm{a}}$ \\
\hline Baseline diastolic blood pressure, ${ }^{a} \mathrm{~mm} \mathrm{Hg}$ & $74.6(10.3)$ & $74.0(9.2)$ & $83.1(10.8) \S^{* *}$ & $<0.005^{a}$ \\
\hline Baseline systolic blood pressure, ${ }^{a} \mathrm{~mm} \mathrm{Hg}$ & $119.3(15.8)$ & $120.5(13.3)$ & $132.0(14.4) \Psi_{1}$, * & $<0.005^{a}$ \\
\hline Baseline mean arterial pressure, ${ }^{\mathrm{a}} \mathrm{mm} \mathrm{Hg}$ & $89.5(11.1)$ & $89.5(9.7)$ & $99.4(11.1) \S$, , & $<0.005^{a}$ \\
\hline CDR-Global >0 & $5(3.9)$ & $59(30.3)^{*}$ & $17(73.9)^{*}$ & $<0.0001^{\mathrm{b}}$ \\
\hline Baseline CDR-SB ${ }^{\mathbf{b}}$ & $0.02(0.10)$ & $1.09(2.64)^{*}$ & $2.13(1.91) \ddagger$ & $<0.0001^{\mathrm{b}}$ \\
\hline Baseline cognitive composite ${ }^{\mathrm{b}}$ (16 missing) & $1.67(0.65)$ & $1.05(1.05)^{\star}$ & $0.31(0.95)^{\star \star}$ & $<0.0001^{\mathrm{b}}$ \\
\hline Baseline Hachinski Ischemia Score ${ }^{a}$ (1 missing) & $0.13(0.46)$ & $0.25(0.73)$ & $1.22(2.21)^{* \dagger}$ & $<0.0001^{\circ}$ \\
\hline Abnormal gait $^{a}$ & $2(1.6)$ & $10(5.1)$ & $4(17.4) \ddagger$ & $<0.05^{\mathrm{a}}$ \\
\hline Tremor $^{a}$ & $5(3.9)$ & $11(5.6)$ & $2(8.7)$ & $0.82^{a}$ \\
\hline Baseline WMH volume, ${ }^{a} \mathrm{~mm}^{3}$ ( 2 missing) & $1,854.8(1,919.1)$ & $4,035.8(7,024.3)$ & $23,040.9(33,957.0)^{*}, \dagger$ & $<0.0001^{\circ}$ \\
\hline Baseline precuneus thickness, ${ }^{a} \mathrm{~mm}$ (8 missing) & $2.38(0.12)$ & $2.30(0.20)^{\star \star}$ & $2.17(0.19)^{\star \star}$ & $<0.0001^{\circ}$ \\
\hline Baseline hippocampal volume, ${ }^{\mathrm{a}} \mathrm{mm}^{3}$ (8 missing) & $8,812.5(655.6)$ & $8,434.9(1,101.8)^{\star *}$ & $7,579.1(1,534.8)^{\star *}, \boldsymbol{\Phi}$ & $<0.0001^{\circ}$ \\
\hline $\mathrm{CMH}_{\text {prevalence }}{ }^{\mathrm{c}}$ & $3(2.4)$ & $7(3.6)$ & $14(60.9)^{\star}, \dagger$ & $<0.0001^{\mathrm{C}}$ \\
\hline CMHs baseline, ${ }^{\mathrm{C}}$ median (lower - upper quartile) & $0.0(0.0-0.0)$ & $0.0(0.0-0.0)$ & $1.0(0.0-6.0)^{*}, \dagger$ & $<0.0001^{\mathrm{C}}$ \\
\hline 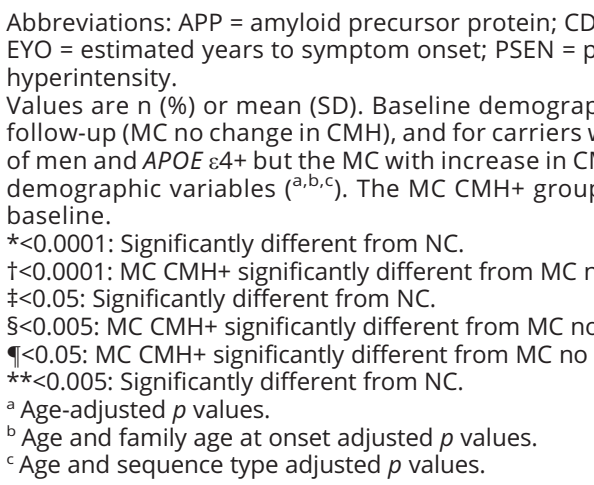 & $\begin{array}{l}\text { Dal = Clinical Deme } \\
\text { lin; PSEN1 post-c2 } \\
\text { ta are shown for } \\
\text { crease in CMHs at } \\
\text { oup was older. Th } \\
\text { particularly affect } \\
\text { t. }\end{array}$ & $\begin{array}{l}\text { ting global score; } C D \\
\text { resenilin-1 mutation } \\
\text { riers (NC), for carrie } \\
\text {-up (MC with increase } \\
\text { was included as a co } \\
\text { cognitive impairmen }\end{array}$ & $\begin{array}{l}\text { Clinical Dementia Ratin } \\
\text { n after codon 200; WM } \\
\text { out change in cerebral } \\
\text { H). The groups had sim } \\
\text { e in the comparisons of } \\
\text { tor impairments, and s }\end{array}$ & $\begin{array}{l}\text { of Boxes, } \\
\text { ite matter } \\
\text { obleeds at } \\
\text { oportions } \\
\text { lependent } \\
\text { history at }\end{array}$ \\
\hline
\end{tabular}




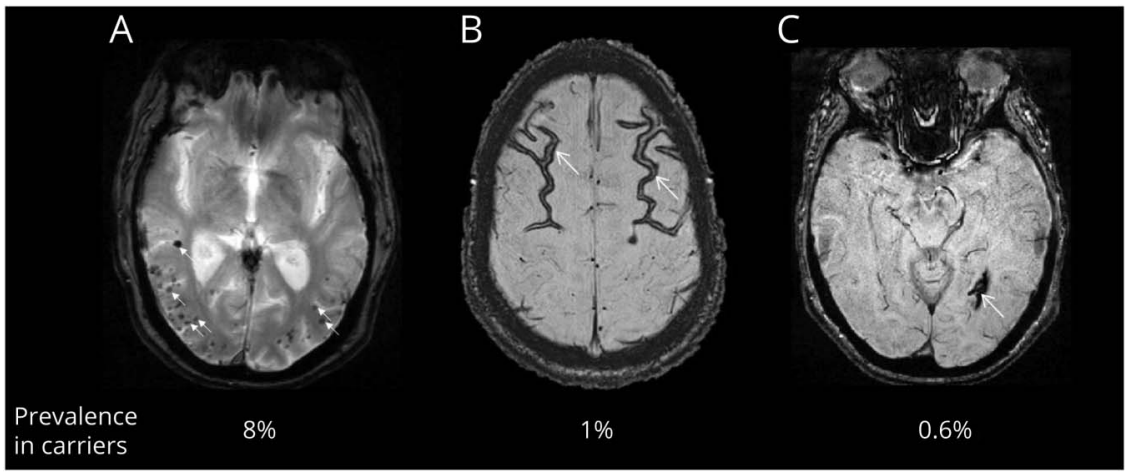

(A) Severe cerebral microhemorrhage $(\mathrm{CMH})$ lesion observed in posterior cortico-subcortical area (arrows indicate several CMHs) on $\mathrm{T}^{*}$ gradient recalled echo. (B) Severe superficial siderosis (arrows) detected on susceptibilityweighted image (SWI). (C) Macrohemorrhage (arrow) observed in temporal area on SWI. In carriers, CMHs (A), superficial siderosis (B), and macrohemorrhages $(C)$ are observed with an overall prevalence of $8 \%, 1 \%$, and $0.6 \%$, respectively.

analyses. Sensitivity analyses were also performed to investigate the effect of other factors such as baseline age, baseline EYO, APOE $\varepsilon 4$ status, sex, MAP, and sequence type. The normality assumption was examined using histograms and the Q-Q (quantile-quantile) plots of the residuals output by the mixed effects models.

All analyses were conducted using SAS 9.4 (SAS Institute Inc., Cary, NC) or R (r-project.org). Missing data during the longitudinal follow-up were considered missing at random. All tests are 2 -sided and $p$ values less than 0.05 are considered significant.

\section{Data Availability}

The DIAN data are available upon request. All requests for data must be submitted in writing via the electronic data request form available at dian.wustl.edu.

\section{Results}

\section{Participant Clinical and Vascular-Related Characteristics in the Presence of CMHs}

The demographics, along with clinical, psychometric, and vascular-related variables of the cross-sectional and longitudinal cohorts, are summarized in tables 1 and 2 . The clinical assessments based on CDR and CDR-SB did not show differences between carriers with and without CMHs, while cognitive assessment with the cognitive composite measure revealed that carriers with $\mathrm{CMHs}$ were more impaired than carriers without $\mathrm{CMH}$ and noncarriers (table 1). Carriers with an increase in $\mathrm{CMH}$ at follow-up were also more cognitively impaired compared to carriers without change in $\mathrm{CMH}$ based on the cognitive composite. These 2 groups were similar in clinical measurements (table 2). It is important to note that carriers with $\mathrm{CMHs}$ and with increased $\mathrm{CMH}$ at follow-up were significantly older and at a more advanced EYO (tables 1 and 2). After controlling for age, carriers with $\mathrm{CMHs}$ had higher prevalence of abnormal gait (table 1), but the prevalence of tremor, diabetes, and hypercholesterolemia was similar in the 3 groups (table 1). Mean arterial blood pressure, diastolic blood pressure, and Hachinski
Ischemic Score were significantly higher in carriers with CMHs (table 1). Carriers with an increase in $\mathrm{CMH}$ count at follow-up presented higher mean arterial blood pressure, diastolic and systolic blood pressure, and Hachinski Ischemic score compared to carriers without change in $\mathrm{CMH}$ at follow-up (table 2). A stroke history was observed only in carriers with CMHs.

\section{CMH Prevalence and Location}

Of all 511 participants, 32 (6.3\%) participants had CMHs at baseline. Of the 310 carriers, $26(8.4 \%)$ had CMHs, whereas of the 201 noncarriers, only $6(3.0 \%)$ had CMHs. The CMH prevalence was $3.0 \%$ and $18.3 \%$ in asymptomatic and symptomatic carriers, respectively. Thirteen participants with baseline SWI had 32 CMHs overall; upon protocol change to T2*-GRE, the same $32 \mathrm{CMHs}$ were again detected, along with additional new CMHs. Stepwise selection of multivariable logistic regression analysis indicated that carriers were more likely to have CMHs compared with noncarriers (OR 3.575, 95\% CI 1.499, 9.904). Age and diastolic blood pressure were also significantly associated with the odds of having CMHs (OR 1.071, 95\% CI 1.034, 1.110 and OR 1.068, 95\% CI 1.030, 1.108, respectively). Controlling for these factors, CDR, systolic blood pressure, MAP, sex, APOE \&4 status (yes vs no), sequence type, and education were not significantly associated with the odds of having CMHs. Within carriers, the mutation type was not associated with the odds of having $\mathrm{CMHs}$. When looking at $\mathrm{CMH}$ severity, a count of 5 or more CMHs was identified in $1.6 \%$ of the overall cohort, all of them mutation carriers $(n=8)$. CMHs were found more in lobar areas than in deep areas, and preferentially in occipital areas (figure 1A). Eighty-one percent of the participants with CMHs $(\mathrm{n}=26)$ had lesions strictly in lobar areas while $3 \%$ had CMHs only in deep areas. Sixteen percent had CMHs in both lobar and deep areas. Only 2 participants (0.6\%) developed CMHs solely located in the cerebellum.

\section{CMHs, Other ARIA-H, and White Matter Lesions}

Besides CMHs, other types of hemorrhagic lesions were also observed on GRE MRI in carriers. Though present in fewer cases, these lesions can be severe (figure 1). Superficial siderosis, corresponding to subarachnoid hemorrhage, was detected in 4 participants with and without CMHs (figure 
Table 3 Dominantly Inherited Alzheimer Disease (DIAD) Mutations With High Incident Cerebral Microhemorrhages (CMHs) per Year and Previously Characterized Mutation-Related Phenotypes

\begin{tabular}{lllll}
\hline Gene & Mutation & $\begin{array}{l}\text { \% Of carriers with }+5 \\
\text { CMHs/year }\end{array}$ & $\begin{array}{l}\text { Highest observed } \\
\text { CMH increase }\end{array}$ & Reported phenotype in literature \\
\hline APP & APPdup & 20 & $+12 \mathrm{CMH} / \mathrm{y}$ & Seizures, intracerebral hemorrhage, severe cerebral amyloid angiopathy \\
\hline PSEN1 & $\mathrm{N} 135 \mathrm{~S}$ & 50 & $+20 \mathrm{CMH} / \mathrm{y}$ & $\begin{array}{l}\text { Cotton-wool plaques, mild amyloid angiopathy, corticospinal tract } \\
\text { pathology }\end{array}$ \\
\hline PSEN1 & $\mathrm{H} 163 \mathrm{R}$ & 8 & $+20 \mathrm{CMH} / \mathrm{y}$ & Myoclonus $^{49}$ \\
\hline PSEN1 & Y288H & 25 & $+9 \mathrm{CMH} / \mathrm{y}$ & Seizure, spastic paraparesis, parkinsonism \\
\hline PSEN1 & A431E & 14 & $+33 \mathrm{CMH} / \mathrm{y}$ & $\begin{array}{l}\text { Spastic paraparesis, widespread white-matter abnormalities in several } \\
\text { patients with motor impairments }\end{array}$
\end{tabular}

Abbreviations: APP = amyloid precursor protein; APPdup = duplication of APP gene; PSEN1 = presenilin- 1 .

1B). The 4 participants were from different mutation types $(2$ PSEN1 and 2 APP mutation carriers); 3 were symptomatic and had or developed new CMHs. The most severe case demonstrated widely spread superficial siderosis in the occipital lobe; this participant was an APP mutation carrier with severe $\mathrm{CMH}$ counts (31, including 10 in the occipital) and a macrohemorrhage in the occipital lobe. Macrohemorrhages were overall observed in 2 APP mutation carriers, both with $\mathrm{CMHs}$ and history of stroke (figure $1 \mathrm{C}$ ). The other APP carrier with macrohemorrhages was a Dutch mutation carrier and presented with moderate $\mathrm{CMH}$ severity at baseline. Interestingly, the participants with the highest number of CMHs in the overall cohort (135 CMHs at baseline) and the highest increase in CMHs (3-139 CMHs over 7 years) did not have any superficial siderosis or macrohemorrhages, suggesting that the severity of CMHs is not always a predictor of the presence of those abnormalities. However, concerning white matter lesions (quantified here as WMH volume), we observed that the severity of $\mathrm{CMH}$ in mutation carriers was associated with increased white matter lesion volume $(p<$ $\left.0.0001, F_{3,208}=26.2\right)$ and with larger volume increase at follow-up $\left(p=0.001, F_{3,244}=5.4\right)$, particularly when 5 or more CMHs were present at baseline $\left(14,847.1 \mathrm{~mm}^{3} / \mathrm{y}, p<\right.$ $0.0001,95 \%$ CI 7,555.6, 22,138.6). Similar results were observed when Dutch mutation carriers were excluded.

\section{$\mathrm{CMH}$ Increase and Baseline Status}

A total of 345 participants had longitudinal data with 2 or more visits over 0.9-9.1 years, with an average of $1.3 \pm 0.6$ years between evaluations. Three (2.4\%) of the 127 noncarriers developed new $\mathrm{CMHs}$ during the follow-up, whereas 23 (10.6\%) of the 218 carriers developed new CMHs (figure 2). Among carriers, 14 (66.7\%) of the 21 with CMHs at baseline developed new CMHs during the follow-up, whereas only 9 (4.6\%) of the 197 carriers without $\mathrm{CMH}$ at baseline developed new CMHs $(p<0.0001$, Fisher exact test, OR 35.6, $95 \%$ CI 12.9, 98.6). Although some mutations presented with $+5 \mathrm{CMH} /$ year (table 3), the odds of increased CMHs was not influenced by the mutation type (PSEN1, PSEN2, or APP). Subgroup analyses showed that Dutch mutation carriers have higher odds of developing new CMHs compared to APP Dutch noncarriers $(p<0.005$, Fisher exact test, OR 5.8, 95\% CI 1.8, 22.6). No association was found regarding the mutation position within PSEN1.

For all participants with CMHs at baseline, the rate of increase in $\mathrm{CMHs}$ per year was $0.01 \pm 0.04$ for noncarriers and $0.58 \pm 3.18$ for carriers overall, but $8.95 \pm 10.04$ for the 13 carriers with 2 $\mathrm{CMHs}$ or more at baseline. In carriers, the rate of $\mathrm{CMH}$ accumulation per year was associated with the number of $\mathrm{CMHs}$ observed at baseline $\left(p<0.0001, F_{3,252}=57.5\right)$. The presence of 2-4 CMHs and more than $4 \mathrm{CMHs}$ at baseline were associated with higher rate of increase per year $(5.9 \mathrm{CMH} /$ year, $p<0.0001$, 95\% CI 4.0, 7.7 and 11.2 CMH/year, $p<0.0001,95 \%$ CI 9.4, 13.1 CMHs, respectively) (figure 3). Similar associations were observed when excluding Dutch mutation carriers.

Figure 4 shows an individual's longitudinal $\mathrm{CMH}$ count as a function of EYO. All participants with more than $2 \mathrm{CMHs}$ and with an increased rate of 2 or more $\mathrm{CMHs}$ per year were symptomatic carriers (figure 4). For carriers, the rate of $\mathrm{CMH}$ occurrence increased near the expected date of symptom onset (figure 4). Based on the generalized linear mixed effects model analysis, only the symptomatic carriers had an increased rate in CMHs during the follow-up (1.62 CMH/year, $p<0.0001,95 \%$ CI $0.95,2.29)$. Similar analyses for $A P O E \varepsilon 4$ status revealed that $A P O E \& 4$ status (noncarrier vs carrier) does not influence the annual CMH increase whether accounting for Dutch mutation carriers or not. Controlling for clinical symptomatic status, sensitivity analyses indicated that baseline age, baseline $\mathrm{MAP}$, change of sequence type during the follow-up, $A P O E \varepsilon 4$, and sex were not associated with the change in CMHs.

\section{$\mathrm{CMH}$ Presence/Increase and Disease Progression}

Among the carriers with longitudinal follow-up, participants with $\mathrm{CMHs}$ or with an increase in CMHs at follow-up were more advanced in expected disease stage. Adjusting for baseline EYO, the LME model showed that having CMHs at baseline or having an increase in CMHs at follow-up was not 


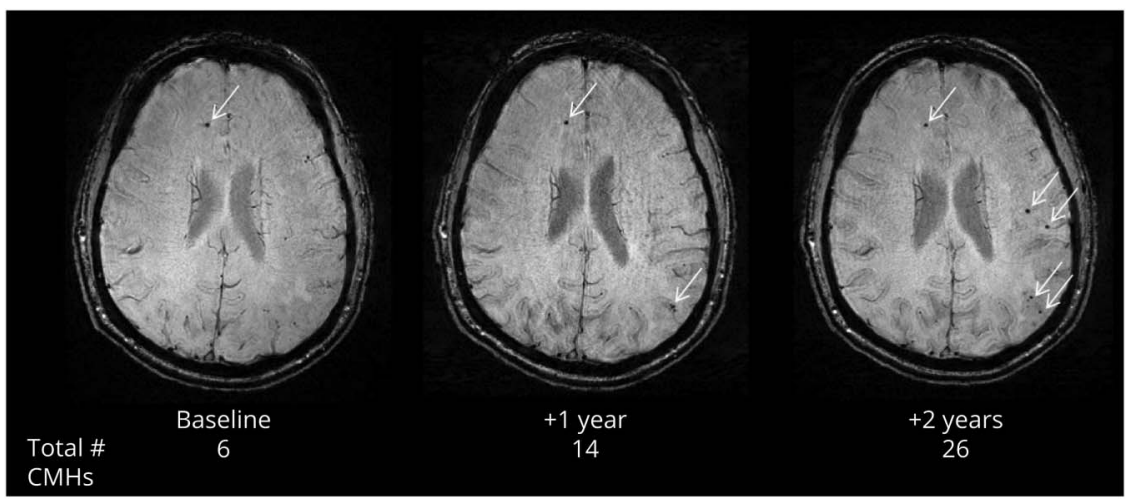

Baseline, 1 year, and 2 year follow-up susceptibility-weighted image scans of 1 participant showing longitudinal accumulation of $\mathrm{CMHs}$ (arrows). The total number of CMHs observed on the overall scan was 6,14 , and 26 , respectively.

associated with faster cortical thinning of precuneus or inferior parietal, hippocampal volume decrease or faster change in white matter lesion volumes. Moreover, participants who had CMHs at baseline demonstrated faster increase in CDRSB $(0.67 / y, p=0.001,95 \%$ CI $0.27,1.07)$ and a larger, but nonsignificant, annual decline in the cognitive composite $(-0.07 / y, p=0.14,95 \%$ CI $-0.16,0.02)$ compared with those without $\mathrm{CMH}$ at baseline. Similarly, carriers with increased CMHs during the follow-up had a faster annual increase in CDR-SB $(0.75 / y, p=0.048,95 \%$ CI 0.01, 1.49) and a larger, but nonsignificant, annual decline in the cognitive composite (-0.07/y, $p=0.38,95 \% \mathrm{CI}-0.21,0.08)$ compared to those without an increase in CMHs. Analyses excluding Dutch mutation carriers did not alter these findings.

\section{Discussion}

In this cross-sectional and longitudinal study, we describe microhemorrhage prevalence, location, severity, and inherent increase in a population with $\mathrm{DIAD}$, allowing study of $\mathrm{AD}$ pathology with reduced influence from confounders of agerelated vascular risk factors. We found that $\mathrm{CMH}$ were associated with worsening of clinical symptoms, occurred primarily after the expected age at symptom onset, and that, once present, they are likely to increase in number over time. These findings have important implications for participant selection and monitoring in clinical trials involving the DIAD population.

Hypertension is a risk factor for cerebral hemorrhagic lesions and a common feature of $\mathrm{AD} .^{2}$ Carriers with $\mathrm{CMHs}$ had mildly elevated blood pressure (MAP $97.6 \pm 9.3 \mathrm{~mm} \mathrm{Hg}$ ) and the presence of CMHs was associated with higher diastolic and mean arterial pressure. However, blood pressure values were not associated with accumulation of $\mathrm{CMHs}$ or cognitive decline. These findings suggest that higher blood pressure may still contribute to CMHs in a relatively young population with a significant risk for $\mathrm{AD}$. CMHs were mainly located in lobar areas with a minority of deep CMHs, supporting the hypothesis that CMHs in the setting of DIAD are largely due to CAA rather than hypertensive arteriopathy. ${ }^{25} \mathrm{~A}$ recent study from Graff-Radford et al. $^{26}$ showed that $A \beta$ burden is associated with lobar CMHs but not deep CMHs in aging populations, which supports CAA as the pathologic substrate for multiple lobar CMHs. Previous studies showed predominance for lobar $\mathrm{CMHs}$ in familial and sporadic $\mathrm{AD}$ populations. ${ }^{1,27}$ CAA has been observed in DIAD populations ${ }^{28}$ with higher frequency than in sporadic $\mathrm{AD},{ }^{29}$ but further postmortem evaluation is needed to correlate CAA and CMHs in DIAD. Diabetes and hypercholesterolemia were not found more frequently in carriers with CMHs.

Regarding clinical risks, carriers with CMHs in our study had more severe gait disorders and cognitive impairment at baseline. $\mathrm{CMHs}$ were previously reported in carriers of specific $\mathrm{DIAD}$ mutations associated with parkinsonism and spastic paraparesis. ${ }^{30}$ It has also been reported that the presence of lobar CMHs predicted worsening of gait and parkinsonism in patients with dementia, including $\mathrm{AD}{ }^{1}$ In our $\mathrm{DIAD}$ cohort, abnormal gait but not tremor was associated with the presence of CMHs. Further study is of interest to better establish the relationship between motor deterioration and $\mathrm{CMH}$ in DIAD. Symptomatic carriers were most likely to develop CMHs and were the only group with a significant increase in $\mathrm{CMHs}$ per year. Only a few occurrences of CMHs were observed before the estimated year of symptoms onset, suggesting a relationship between disease progression and occurrence of CMHs. A large study involving 3,257 participants showed that the presence of CMHs was associated with an increased risk for dementia, including $\mathrm{AD}$, and that the presence of more than $4 \mathrm{CMHs}$ was associated with cognitive decline. ${ }^{23}$ In our study, DIAD mutation carriers declined faster as measured by CDR-SB when they had CMHs or developed more CMHs.

Our cross-sectional cohort was larger than the longitudinal one due to recent participants having only baseline evaluations and due to participants' transfer from the DIAN Observational Study to the DIAN Trials Unit. However, the 2 cohorts presented similar clinical characteristics, suggesting 
Figure 3 Increase of Cerebral Microhemorrhages (CMHs) as a Function of the Number of CMHs at Baseline in Carriers

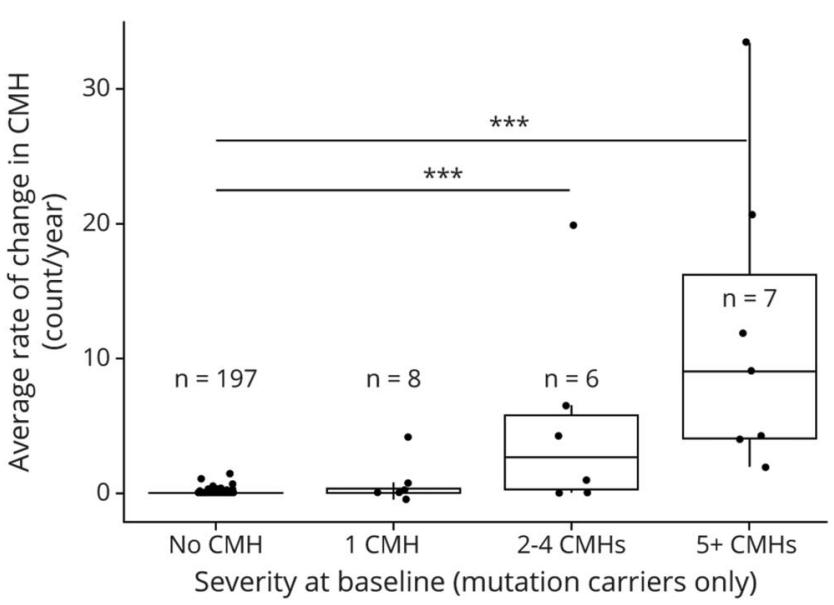

In mutation carriers $(\mathrm{n}=218)$, the rate of $\mathrm{CMH}$ accumulation per year was different as a function of the number of $\mathrm{CMHs}$ observed at baseline. The presence of 2-4 CMHs (moderate $\mathrm{CMH}$ count) and more than $5 \mathrm{CMHs}$ (severe $\mathrm{CMH}$ count) at baseline predicted a higher rate of increase in $\mathrm{CMHs}$ at follow-up (5.9 \pm 0.9 and $11.2 \pm 0.9 \mathrm{CMH}$ s per year, respectively) relative to the group with no $\mathrm{CMH}$ at baseline. ${ }^{\star \star *} p<0.0001$.

comparability between cross-sectional and longitudinal analyses. As an international, multisite, longitudinal study, we harmonize protocols across sites. In our dataset, participants had either SWI or T2*-GRE sequences at each evaluation, with some sites changing from SWI to T2*-GRE for harmonization. Although the T2*-GRE employed was specifically tailored for sensitivity $(\sim 2.5$ minutes acquisition time instead of traditional 30-second scan), this raises concerns regarding differences in detection sensitivity. ${ }^{31}$ All CMHs observed on SWI were detected on subsequent T2*-GRE, suggesting no underdiagnosis of $\mathrm{CMHs}$ with the change in protocol. Moreover, sensitive analyses showed no effect of sequence type on $\mathrm{CMH}$ detection.

The prevalence of CMHs varies across studies on DIAD populations. Whereas Ryan et al., ${ }^{27}$ in a study including 12 individuals with DIAD, observed $25 \%$ prevalence of CMHs, a previous DIAN study of 175 participants reported a $15 \%$ prevalence of CMHs. ${ }^{32}$ Here we evaluated 511 participants and found around $8 \%$ of mutation carriers with CMHs. Note that the mean age of these studies on DIAD is below 50 years while studies on sporadic $\mathrm{AD}$ reported a prevalence of $\mathrm{CMHs}$ of $23 \%-24 \%$ in cohorts with a mean age above 67 years. ${ }^{33}$

In our study, age was an important factor for $\mathrm{CMH}$ prevalence even though the group is relatively young ( $46.7 \pm 10.5$ years for carriers with CMHs). Thus, the age of our population and the variability in CMHs counts raise the question of the role of genetic factors. ${ }^{34}$ Several studies reported increased risk of vascular disease associated with specific mutations, particularly within the APP and PSEN1 genes. ${ }^{27}$ The APP Dutch mutation (Glu693Gln) is associated with CAA and cerebral
Figure 4 Longitudinal Accumulation of Cerebral Microhemorrhages (CMHs) as a Function of Estimated Years to Symptom Onset

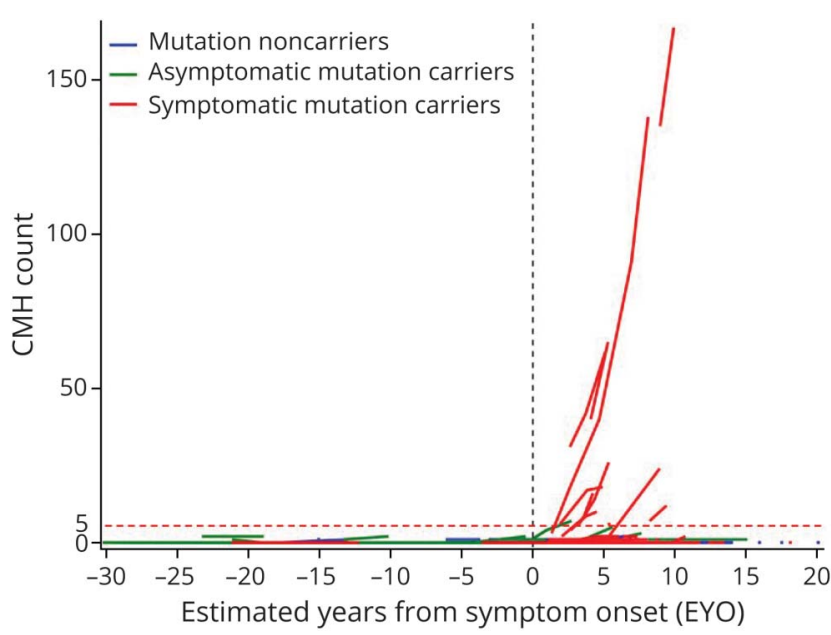

Plot of $\mathrm{CMH}$ count as a function of estimated years from symptom onset (EYO) within mutation noncarriers (blue, $n=127$ ), asymptomatic mutation carriers (green, $n=142$ ), and symptomatic mutation carriers (red, $n=76$ ). Accumulation of $\mathrm{CMH}$ is more pronounced (increase to $>5 \mathrm{CMHs}$, above red dashed line) and mostly observed in symptomatic mutation carriers ( $\mathrm{n}=17$, 22.4\%) past EYO 0 (black dashed line). Three noncarriers (2.4\%) and 6 asymptomatic mutation carriers (4.2\%) had new CMHs to a lesser extent (increase to $<5 \mathrm{CMHs}$, under red dashed line).

hemorrhage, reporting $\mathrm{CMH}$ prevalence of more than $60 \% .^{35}$ PSEN1 mutations after the codon 200 are possibly associated with severe CAA. ${ }^{36}$ Using Exact tests for our small group size, the odds of having CMHs or developing new $\mathrm{CMH}$ was not influenced by mutation type (PSEN1, PSEN2, or APP) among carriers. Analyses of subgroups within APP (Dutch vs nonDutch) or PSEN1 (before vs after codon 200) mutation carriers revealed increased risk for incident CMHs in Dutch mutation carriers. However, none of the findings excluding Dutch mutation carriers were different, suggesting that our findings were not driven by this group. The APOE $\varepsilon 4$ allele has been shown to be associated with increased risk for developing $\mathrm{CMHs} \mathrm{s}^{37,38}$ but this risk was not necessarily found in relation to the Dutch mutation. ${ }^{39}$ In our study, though we could not establish a clear relationship with specific mutation types, the APOE \&4 allele was not associated with increased risk for developing CMHs regardless of the inclusion of Dutch mutation carriers. These findings demonstrate the variability of genotype-phenotype relationships and the difficulty of relying on genotype to estimate risks for vascular disorders in disease progression and during clinical trials.

Previous studies showed that the presence of CMHs was associated with the presence of superficial siderosis ${ }^{40}$ and indicates increased risk for future macroscopic hemorrhages. ${ }^{41,42}$ A study in normal aging reported a $0.2 \%$ prevalence of superficial siderosis with $23 \%$ of cases with superficial siderosis also having $\mathrm{CMHs}^{43}$ In our study, $0.19 \%$ of the overall cohort had superficial siderosis and half of those with widely spread lesions had CMHs. The 2 participants in the current study with 
macrohemorrhages had a history of stroke and CMHs with differing severity ( 2 and 31 lobar $\mathrm{CMHs}$ ). However, participants with the highest $\mathrm{CMH}$ counts (135 lobar CMHs) and with the greatest rate of change in $\mathrm{CMHs}$ did not have any superficial siderosis, macrohemorrhages, or history of stroke, suggesting that a high number of $\mathrm{CMHs}$ is not necessarily associated with preexisting superficial siderosis or macrohemorrhages.

Whereas in this study we focused on ARIA-H, previous studies found that ARIA edema types (ARIA-E) are closely associated with the presence of CMHs. In our cohort, only one participant had possible ARIA-E and we found no clear evidence for a relationship with CMHs. WMH also observed on FLAIR is a small vessel disease-related abnormality more commonly observed in $\mathrm{AD},{ }^{44}$ including DIAD. ${ }^{45}$ A previous DIAN study demonstrated that white matter lesions were greater in individuals with CMHs compared to those without $\mathrm{CMHs}$ and the presence of CMHs was associated with increased WMH volume. ${ }^{32}$ We confirmed this finding with our dataset. Having 5 or more CMHs was particularly associated with change in WMH volume. However, having incident $\mathrm{CMHs}$ was not associated with worsening WMH.

Mutation carriers were particularly at risk for developing $\mathrm{CMHs}$ and the presence of CMHs at baseline was related to risk for increase in $\mathrm{CMH}$ prevalence within 2 years. The presence of CMHs is itself a risk for an increase in CMHs without any treatments, as shown by the accumulation of $\mathrm{CMHs}$ over time in our population followed longitudinally. Studies in a healthy elderly population, ${ }^{3}$ preclinical $\mathrm{AD},{ }^{38}$ and a memory clinic population ${ }^{46}$ showed that occurrence of new $\mathrm{CMHs}$ is linked to baseline CMHs and reported ORs from 5 to 8 , suggesting predictable development of new $\mathrm{CMHs}$ when $\mathrm{CMHs}$ are present at baseline. Here, we report a smaller OR of 3.6 for our cohort. However, while those studies reported that $10 \%-12 \%$ of participants developed new CMHs, we observed that $66.7 \%$ of the carriers who already had $\mathrm{CMHs}$ developed new $\mathrm{CMHs}$ at follow-up in our DIAD population. Incidence of CMHs was not associated with progressive brain atrophy but was associated with worsening dementia as measured by CDR-SB. The exponential and quasisystematic increase of CMHs makes these findings critical for clinical trial monitoring. For participants in clinical trials at risk for developing ARIA-H as a complication, it will be important to try to separate the natural incidence of CMHs from adverse events related to therapy. $\mathrm{A} \beta$-modifying therapies, such as passive immunotherapy with bapineuzumab, induced $\mathrm{CMHs}$ in patients with $\mathrm{AD}$ and studies confirmed that the odds to develop CMHs after treatment were increased. ${ }^{37}$ Based on these clinical trial outcomes, $\mathrm{AD}$ working groups recommended excluding participants with more than $5 \mathrm{CMHs}$ (defined in our study as a severe $\mathrm{CMH}$ finding). ${ }^{6}$ In DIAD, having 2-4 CMHs (defined as moderate $\mathrm{CMH}$ severity) is a risk factor for developing more and the odds of increase appear higher than what has been reported in sporadic $\mathrm{AD}$. Based on these results, recommendation guidelines for $\mathrm{CMHs}$ in such populations may need to be revisited and adapted for familial AD. This study additionally shows that any clinical trial on individuals with DIAD needs careful participant selection and monitoring.

\section{Acknowledgment}

The authors thank the participants and their families and all the researchers of the Dominantly Inherited Alzheimer Network. Data collection and sharing for this project was supported by the Dominantly Inherited Alzheimers Network (DIAN, UF1AG032438) funded by the National Institute on Aging (NIA), the German Center for Neurodegenerative Diseases (DZNE), Raul Carrea Institute for Neurological Research (FLENI), partial support by the Research and Development Grants for Dementia from Japan Agency for Medical Research and Development, AMED, and the Korea Health Technology R\&D Project through the Korea Health Industry Development Institute (KHIDI). This article has been reviewed by DIAN study investigators for scientific content and consistency of data interpretation with previous DIAN study publications. The authors thank the participants and their families and contributions of the DIAN research and support staff at each of the participating sites for their contributions to this study. This work was supported by the NIH/NIA (U01AG042791, UF1AG032438). Data management and computations were made possible using the facilities of the Washington University Center for High Performance Computing and the Central Neuroimaging Data Archive (CNDA)/Neuroimaging Informatics and Analysis Center (NIAC) (1P30NS098577, R01 EB009352).

\section{Study Funding}

Study funded by NIH/NIA U01AG032438.

\section{Disclosure}

Dr. Joseph-Mathurin receives research support from the Alzheimers Association through the International Research Grant Program (AARFD-20-681815). G. Wang reports no disclosures relevant to the manuscript. K. Kantarci serves on the data safety monitoring board for Takeda Global Research and Development Center, Inc; receives research support from Avid Radiopharmaceuticals and Eli Lilly; and receives funding from NIH and Alzheimers Drug Discovery Foundation. C.R. Jack, Jr. serves on an independent data monitoring board for Roche, has consulted for and served as a speaker for Eisai, and consulted for Biogen, but he receives no personal compensation from any commercial entity; and receives research support from $\mathrm{NIH}$ and the Alexander Family Alzheimers Disease Research Professorship of the Mayo Clinic. E. McDade reports no disclosures relevant to the manuscript. J. Hassenstab is an advisory board member for Roche, DSMB member for Eisai, and consultant for Lundbeck and Takeda. T.M. Blazey and B.A. Gordon report no disclosures relevant to the manuscript. Y. Su was a paid consultant for Green Valley Pharmaceuticals in 2018. G. Chen, P. Massoumzadeh, R.C. Hornbeck, R.F. Allegri, B.M. Ances, and S.B. Berman report no disclosures relevant to the manuscript. A.M. Brickman has served on the scientific advisory board of Keystone Heart; serves on 
DSMB of a National Institutes of Aging supported study of a dietary intervention; is an editorial board member of The Journal of the International Neuropsychological Society, editorial board member of Neuropsychology Review, associate editor of Neurodegenerative Diseases, and editorial board member of Alzheimers \& Dementia; has a US patent: Technologies for white matter hyperintensity quantification and a pending US patent: Methods and systems for evaluating age-related memory loss; is a consultant for ProPhase and Cognition Therapeutics and was a consultant for Keystone Heart; receives laboratory research funding from the $\mathrm{NIH}$ and has received funding from Columbia University, Alzheimers Association, and Mary E. Groff Surgical Medical Research and Education Charitable Trust; receives shares in Mars Holding Limited; and provided expert witness consultation for the Flomenhaft Law Firm. W.S. Brooks and D.M. Cash report no disclosures relevant to the manuscript. J.P. Chhatwal has served on a medical advisory board for Otsuka Pharmaceuticals. H.C. Chui and S. Correia report no disclosures relevant to the manuscript $C$. Cruchaga receives research support from Biogen, EISAI, Alector, and Parabon [the funders of the study had no role in the collection, analysis, or interpretation of data; in the writing of the report; or in the decision to submit the paper for publication]; and is a member of the advisory board of Vivid genetics, Halia Therapeutics, and $\mathrm{ADx}$ Healthcare. M.R. Farlow receives support from AbbVie, ADCS Posiphen, AstraZeneca, Biogen, Eisai, Eli Lilly, Genentech, Novartis, Suven Life Sciences, Ltd., and vTv Therapeutics; and is a member of the advisory boards of Allergan, Avanir, AZTherapies, Biogen MA Inc., Cerecin (formerly Accera), Chemigen, Cognition Therapeutics, Cortexyme, Danone, Eisai Inc., Eli Lilly \& Company, Longeveron, Green Valley, Medavante, Otsuka Pharmaceutical, Proclara (formerly Neurophage Pharmaceuticals), Neurotrope Biosciences, Samumed, Takeda, vTv Therapeutics, and Zhejian Hisun Pharmaceuticals. N.C. Fox receives research support from Roche, Biogen, and Ionis; serves on a Data Safety Monitoring Board for Biogen; and acknowledges support from Alzheimer's Research UK, the UK Dementia Research Institute, and the NIHR UCLH Biomedical Research Centre. M. Fulham, B. Ghetti, N. Graff-Radford, K.A. Johnson, C.M. Karch, and C. Laske report no disclosures relevant to the manuscript. A.K.W. Lee is partially supported by Institutional Development Award Number U54GM115677 from the National Institute of General Medical Sciences of the NIH, which funds Advance Clinical and Translational Research (Advance-CTR) (the content is solely the responsibility of the authors and does not necessarily represent the official views of the NIH). J. Levin, C.L. Masters, J.M. Noble, A. O’Connor, RJ. Perrin, G.M. Preboske, J.M. Ringman, and C.C. Rowe report no disclosures relevant to the manuscript. S. Salloway receives consultation and research support from Biogen, Eisai, Genentech, Novartis, Roche, Lilly, and AVID. A.J. Saykin received research support from Avid Radiopharmaceuticals and Eli Lilly unrelated to the present study, as well as support from multiple NIA and NCI grants. P.R. Schofield, H. Shimada, M. Shoji, K. Suzuki, V.L. Villemagne, C. Xiong, and I. Yakushev report no disclosures relevant to the manuscript. J.C. Morris is funded by NIH grants P30 AG066444, P01AG003991, P01AG026276, and U19 AG032438; neither Dr. Morris nor his family owns stock or has equity interest (outside of mutual funds or other externally directed accounts) in any pharmaceutical or biotechnology company. RJ. Bateman receives support unrelated to the Dominantly Inherited Alzheimer Network; laboratory research funding from the NIH, Alzheimers Association, BrightFocus Foundation, Rainwater Foundation Tau Consortium, Association for Frontotemporal Degeneration, the Cure Alzheimers Fund, the Tau SILK Consortium (AbbVie, Biogen, and Eli Lilly and Co.), and an anonymous foundation (funding for clinical trials includes the NIH, Alzheimer's Association, Eli Lilly and Co, Hoffman La-Roche, Janssen, Avid Radiopharmaceuticals, GHR Foundation, and an anonymous foundation); receives research funding from the DIAN-TU Pharma Consortium (AbbVie, Biogen, Eisai, Eli Lilly and Co/Avid Radiopharmaceuticals, Hoffman La-Roche/Genentech, Janssen, and United Neuroscience; has received honoraria from Roche as an Advisory Board member; Washington University, R.J.B., and D.M.H. have equity ownership interest in $\mathrm{C} 2 \mathrm{~N}$ Diagnostics and receive royalty income based on technology (stable isotope labeling kinetics and blood plasma assay) licensed by Washington University to C2N Diagnostics; receives income from C2N Diagnostics for serving on the scientific advisory board; and Washington University, with R.J.B. as coinventor, has submitted the US nonprovisional patent application: Methods for measuring the metabolism of CNS derived biomolecules in vivo and provisional patent application: Plasma based methods for detecting CNS amyloid deposition. T.L.S. Benzinger participates as a site investigator in clinical trials sponsored by Avid Radiopharmaceuticals, Eli Lilly, Biogen, Janssen, and Roche; serves as an unpaid consultant to Eisai and Siemens; and is on the Speaker's Bureau for Biogen. Go to Neurology.org/ $\mathrm{N}$ for full disclosures.

\section{Publication History}

Received by Neurology March 23, 2020. Accepted in final form December 10, 2020.

\begin{tabular}{|c|c|c|}
\hline Name & Location & Contribution \\
\hline $\begin{array}{l}\text { Nelly Joseph- } \\
\text { Mathurin, PhD }\end{array}$ & $\begin{array}{l}\text { Washington University } \\
\text { School of Medicine, St. } \\
\text { Louis, MO }\end{array}$ & $\begin{array}{l}\text { Designed and } \\
\text { conceptualized study, } \\
\text { analyzed the data, } \\
\text { drafted and revised the } \\
\text { manuscript for } \\
\text { intellectual content }\end{array}$ \\
\hline $\begin{array}{l}\text { Guoqiao Wang, } \\
\text { PhD }\end{array}$ & $\begin{array}{l}\text { Washington University } \\
\text { School of Medicine, St. } \\
\text { Louis, MO }\end{array}$ & $\begin{array}{l}\text { Data analysis, drafting } \\
\text { and revision of } \\
\text { manuscript for } \\
\text { intellectual content }\end{array}$ \\
\hline $\begin{array}{l}\text { Kejal Kantarci, } \\
\text { MD, MS }\end{array}$ & $\begin{array}{l}\text { Mayo Clinic, Rochester, } \\
\text { MN }\end{array}$ & $\begin{array}{l}\text { Data collection and } \\
\text { analysis, revision of } \\
\text { manuscript for } \\
\text { intellectual content }\end{array}$ \\
\hline $\begin{array}{l}\text { Clifford R. Jack, } \\
\text { Jr., MD }\end{array}$ & $\begin{array}{l}\text { Mayo Clinic, Rochester, } \\
\text { MN }\end{array}$ & $\begin{array}{l}\text { Data collection and } \\
\text { analysis, revision of } \\
\text { manuscript for } \\
\text { intellectual content }\end{array}$ \\
\hline Eric McDade, DO & $\begin{array}{l}\text { Washington University } \\
\text { School of Medicine, St. } \\
\text { Louis, MO }\end{array}$ & $\begin{array}{l}\text { Data analysis, drafting } \\
\text { and revision of } \\
\text { manuscript for } \\
\text { intellectual content }\end{array}$ \\
\hline
\end{tabular}


Appendix 1 (continued)

\begin{tabular}{|c|c|c|}
\hline Name & Location & Contribution \\
\hline $\begin{array}{l}\text { Jason } \\
\text { Hassenstab, PhD }\end{array}$ & $\begin{array}{l}\text { Washington University } \\
\text { School of Medicine, St. } \\
\text { Louis, MO }\end{array}$ & $\begin{array}{l}\text { Data collection and } \\
\text { analysis, drafting and } \\
\text { revision of manuscript } \\
\text { for intellectual } \\
\text { content }\end{array}$ \\
\hline $\begin{array}{l}\text { Tyler M. Blazey, } \\
\text { PhD }\end{array}$ & $\begin{array}{l}\text { Washington University } \\
\text { School of Medicine, St. } \\
\text { Louis, MO }\end{array}$ & $\begin{array}{l}\text { Data analysis, drafting } \\
\text { and revision of } \\
\text { manuscript for } \\
\text { intellectual content }\end{array}$ \\
\hline $\begin{array}{l}\text { Brian A. Gordon, } \\
\text { PhD }\end{array}$ & $\begin{array}{l}\text { Washington University } \\
\text { School of Medicine, St. } \\
\text { Louis, MO }\end{array}$ & $\begin{array}{l}\text { Revision of manuscript } \\
\text { for intellectual content }\end{array}$ \\
\hline Yi Su, PhD & $\begin{array}{l}\text { Banner Alzheimer's } \\
\text { Institute, Phoenix, AZ }\end{array}$ & $\begin{array}{l}\text { Revision of manuscript } \\
\text { for intellectual content }\end{array}$ \\
\hline $\begin{array}{l}\text { Gengsheng } \\
\text { Chen, PhD }\end{array}$ & $\begin{array}{l}\text { Washington University } \\
\text { School of Medicine, St. } \\
\text { Louis, MO }\end{array}$ & $\begin{array}{l}\text { Revision of manuscript } \\
\text { for intellectual content }\end{array}$ \\
\hline $\begin{array}{l}\text { Parinaz } \\
\text { Massoumzadeh, } \\
\text { PhD }\end{array}$ & $\begin{array}{l}\text { Washington University } \\
\text { School of Medicine, St. } \\
\text { Louis, MO }\end{array}$ & $\begin{array}{l}\text { Revision of manuscript } \\
\text { for intellectual content }\end{array}$ \\
\hline $\begin{array}{l}\text { Russ C. } \\
\text { Hornbeck, MSc }\end{array}$ & $\begin{array}{l}\text { Washington University } \\
\text { School of Medicine, St. } \\
\text { Louis, MO }\end{array}$ & $\begin{array}{l}\text { Data collection, revision } \\
\text { of manuscript for } \\
\text { intellectual content }\end{array}$ \\
\hline $\begin{array}{l}\text { Ricardo F. } \\
\text { Allegri, MD }\end{array}$ & $\begin{array}{l}\text { Instituto de } \\
\text { Investigaciones } \\
\text { Neurológicas Fleni, } \\
\text { Buenos Aires, } \\
\text { Argentina }\end{array}$ & $\begin{array}{l}\text { Data collection, revision } \\
\text { of manuscript for } \\
\text { intellectual content }\end{array}$ \\
\hline $\begin{array}{l}\text { Beau M. Ances, } \\
\text { MD, PhD }\end{array}$ & $\begin{array}{l}\text { Washington University } \\
\text { School of Medicine, St. } \\
\text { Louis, MO }\end{array}$ & $\begin{array}{l}\text { Revision of manuscript } \\
\text { for intellectual content }\end{array}$ \\
\hline $\begin{array}{l}\text { Sarah B. } \\
\text { Berman, MD, } \\
\text { PhD }\end{array}$ & $\begin{array}{l}\text { University of Pittsburgh } \\
\text { School of Medicine, PA }\end{array}$ & $\begin{array}{l}\text { Data collection, revision } \\
\text { of manuscript for } \\
\text { intellectual content }\end{array}$ \\
\hline $\begin{array}{l}\text { Adam M. } \\
\text { Brickman, PhD }\end{array}$ & $\begin{array}{l}\text { Columbia University } \\
\text { Medical Center, New } \\
\text { York, NY }\end{array}$ & $\begin{array}{l}\text { Data collection, revision } \\
\text { of manuscript for } \\
\text { intellectual content }\end{array}$ \\
\hline $\begin{array}{l}\text { William S. } \\
\text { Brooks, MB BS }\end{array}$ & $\begin{array}{l}\text { Neuroscience Research } \\
\text { Australia, Sydney }\end{array}$ & $\begin{array}{l}\text { Data collection, revision } \\
\text { of manuscript for } \\
\text { intellectual content }\end{array}$ \\
\hline $\begin{array}{l}\text { David M. Cash, } \\
\text { PhD }\end{array}$ & $\begin{array}{l}\text { UCL Queen Square } \\
\text { Institute of Neurology, } \\
\text { London, UK }\end{array}$ & $\begin{array}{l}\text { Revision of manuscript } \\
\text { for intellectual content }\end{array}$ \\
\hline $\begin{array}{l}\text { Jasmeer P. } \\
\text { Chhatwal, MD, } \\
\text { PhD }\end{array}$ & $\begin{array}{l}\text { Brigham and Women's } \\
\text { Hospital, Massachusetts } \\
\text { General Hospital, Boston }\end{array}$ & $\begin{array}{l}\text { Data collection, revision } \\
\text { of manuscript for } \\
\text { intellectual content }\end{array}$ \\
\hline $\begin{array}{l}\text { Helena C. Chui, } \\
\text { MD }\end{array}$ & $\begin{array}{l}\text { Keck School of Medicine } \\
\text { of USC, Los Angeles, CA }\end{array}$ & $\begin{array}{l}\text { Data collection, revision } \\
\text { of manuscript for } \\
\text { intellectual content }\end{array}$ \\
\hline $\begin{array}{l}\text { Stephen Correia, } \\
\text { PhD }\end{array}$ & $\begin{array}{l}\text { Butler Hospital, Brown } \\
\text { University Alpert } \\
\text { Medical School, } \\
\text { Providence, RI }\end{array}$ & $\begin{array}{l}\text { Data collection, revision } \\
\text { of manuscript for } \\
\text { intellectual content }\end{array}$ \\
\hline $\begin{array}{l}\text { Carlos Cruchaga, } \\
\text { PhD }\end{array}$ & $\begin{array}{l}\text { Washington University } \\
\text { School of Medicine, St. } \\
\text { Louis, MO }\end{array}$ & $\begin{array}{l}\text { Data collection, revision } \\
\text { of manuscript for } \\
\text { intellectual content }\end{array}$ \\
\hline $\begin{array}{l}\text { Martin R. } \\
\text { Farlow, MD }\end{array}$ & $\begin{array}{l}\text { Indiana University } \\
\text { School of Medicine, } \\
\text { Indianapolis }\end{array}$ & $\begin{array}{l}\text { Data collection, revision } \\
\text { of manuscript for } \\
\text { intellectual content }\end{array}$ \\
\hline
\end{tabular}

Appendix 1 (continued)

\begin{tabular}{|c|c|c|}
\hline Name & Location & Contribution \\
\hline Nick C. Fox, MD & $\begin{array}{l}\text { UCL Queen Square } \\
\text { Institute of Neurology, } \\
\text { London, UK }\end{array}$ & $\begin{array}{l}\text { Data collection, revision } \\
\text { of manuscript for } \\
\text { intellectual content }\end{array}$ \\
\hline $\begin{array}{l}\text { Michael Fulham, } \\
\text { MD }\end{array}$ & $\begin{array}{l}\text { University of Sydney and } \\
\text { Royal Prince Alfred } \\
\text { Hospital, Australia }\end{array}$ & $\begin{array}{l}\text { Data collection, revision } \\
\text { of manuscript for } \\
\text { intellectual content }\end{array}$ \\
\hline $\begin{array}{l}\text { Bernardino } \\
\text { Ghetti, MD }\end{array}$ & $\begin{array}{l}\text { Indiana University } \\
\text { School of Medicine, } \\
\text { Indianapolis }\end{array}$ & $\begin{array}{l}\text { Data collection, revision } \\
\text { of manuscript for } \\
\text { intellectual content }\end{array}$ \\
\hline $\begin{array}{l}\text { Neill Graff- } \\
\text { Radford, MD }\end{array}$ & $\begin{array}{l}\text { Mayo Clinic, Jacksonville, } \\
\text { FL }\end{array}$ & $\begin{array}{l}\text { Data collection, revision } \\
\text { of manuscript for } \\
\text { intellectual content }\end{array}$ \\
\hline $\begin{array}{l}\text { Keith A. Johnson, } \\
\text { MD }\end{array}$ & $\begin{array}{l}\text { Massachusetts General } \\
\text { Hospital, Boston }\end{array}$ & $\begin{array}{l}\text { Data collection, revision } \\
\text { of manuscript for } \\
\text { intellectual content }\end{array}$ \\
\hline $\begin{array}{l}\text { Celeste M. } \\
\text { Karch, PhD }\end{array}$ & $\begin{array}{l}\text { Washington University } \\
\text { School of Medicine, St. } \\
\text { Louis, MO }\end{array}$ & $\begin{array}{l}\text { Revision of manuscript } \\
\text { for intellectual content }\end{array}$ \\
\hline $\begin{array}{l}\text { Christoph Laske, } \\
\text { MD }\end{array}$ & $\begin{array}{l}\text { German Center for } \\
\text { Neurodegenerative } \\
\text { Diseases (DZNE), } \\
\text { Tübingen, Germany }\end{array}$ & $\begin{array}{l}\text { Data collection, revision } \\
\text { of manuscript for } \\
\text { intellectual content }\end{array}$ \\
\hline $\begin{array}{l}\text { Athene K.W. Lee, } \\
\text { PhD }\end{array}$ & $\begin{array}{l}\text { Butler Hospital, Brown } \\
\text { University Alpert } \\
\text { Medical School, } \\
\text { Providence, RI }\end{array}$ & $\begin{array}{l}\text { Data collection, revision } \\
\text { of manuscript for } \\
\text { intellectual content }\end{array}$ \\
\hline $\begin{array}{l}\text { Johannes Levin, } \\
\text { MD, PhD }\end{array}$ & $\begin{array}{l}\text { German Center for } \\
\text { Neurodegenerative } \\
\text { Diseases (DZNE) Munich, } \\
\text { Germany }\end{array}$ & $\begin{array}{l}\text { Data collection, revision } \\
\text { of manuscript for } \\
\text { intellectual content }\end{array}$ \\
\hline $\begin{array}{l}\text { Colin L. Masters, } \\
\text { MD }\end{array}$ & $\begin{array}{l}\text { University of Melbourne, } \\
\text { Victoria, Australia }\end{array}$ & $\begin{array}{l}\text { Data collection, revision } \\
\text { of manuscript for } \\
\text { intellectual content }\end{array}$ \\
\hline $\begin{array}{l}\text { James M. Noble, } \\
\text { MD, MS }\end{array}$ & $\begin{array}{l}\text { Columbia University } \\
\text { Medical Center, New } \\
\text { York, NY }\end{array}$ & $\begin{array}{l}\text { Data collection, revision } \\
\text { of manuscript for } \\
\text { intellectual content }\end{array}$ \\
\hline $\begin{array}{l}\text { Antoinette } \\
\text { O'Connor, } \\
\text { MRCPI }\end{array}$ & $\begin{array}{l}\text { UCL Queen Square } \\
\text { Institute of Neurology, } \\
\text { London, UK }\end{array}$ & $\begin{array}{l}\text { Data collection, revision } \\
\text { of manuscript for } \\
\text { intellectual content }\end{array}$ \\
\hline $\begin{array}{l}\text { Richard J. Perrin, } \\
\text { MD, PhD }\end{array}$ & $\begin{array}{l}\text { Washington University } \\
\text { School of Medicine, St. } \\
\text { Louis, MO }\end{array}$ & $\begin{array}{l}\text { Revision of manuscript } \\
\text { for intellectual content }\end{array}$ \\
\hline $\begin{array}{l}\text { Gregory M. } \\
\text { Preboske, MSc }\end{array}$ & $\begin{array}{l}\text { Mayo Clinic, Rochester, } \\
\text { MN }\end{array}$ & $\begin{array}{l}\text { Data collection and } \\
\text { analysis, revision of } \\
\text { manuscript for } \\
\text { intellectual content }\end{array}$ \\
\hline $\begin{array}{l}\text { John M. } \\
\text { Ringman, MD }\end{array}$ & $\begin{array}{l}\text { Keck School of Medicine } \\
\text { of USC, Los Angeles, CA }\end{array}$ & $\begin{array}{l}\text { Data collection, Revision } \\
\text { of manuscript for } \\
\text { intellectual content }\end{array}$ \\
\hline $\begin{array}{l}\text { Christopher C. } \\
\text { Rowe, MD }\end{array}$ & $\begin{array}{l}\text { University of Melbourne, } \\
\text { Victoria, Australia }\end{array}$ & $\begin{array}{l}\text { Data collection, revision } \\
\text { of manuscript for } \\
\text { intellectual content }\end{array}$ \\
\hline $\begin{array}{l}\text { Stephen } \\
\text { Salloway, MD, } \\
\text { MS }\end{array}$ & $\begin{array}{l}\text { Butler Hospital, Brown } \\
\text { University Alpert } \\
\text { Medical School, } \\
\text { Providence, RI }\end{array}$ & $\begin{array}{l}\text { Data collection, revision } \\
\text { of manuscript for } \\
\text { intellectual content }\end{array}$ \\
\hline $\begin{array}{l}\text { Andrew J. } \\
\text { Saykin, PsyD }\end{array}$ & $\begin{array}{l}\text { Indiana University } \\
\text { School of Medicine, } \\
\text { Indianapolis }\end{array}$ & $\begin{array}{l}\text { Data collection, revision } \\
\text { of manuscript for } \\
\text { intellectual content }\end{array}$ \\
\hline
\end{tabular}

Continued 
Appendix 1 (continued)

\begin{tabular}{|c|c|c|}
\hline Name & Location & Contribution \\
\hline $\begin{array}{l}\text { Peter R. } \\
\text { Schofield, PhD, } \\
\text { DSc }\end{array}$ & $\begin{array}{l}\text { Neuroscience Research } \\
\text { Australia and UNSW } \\
\text { Sydney }\end{array}$ & $\begin{array}{l}\text { Data collection, revision } \\
\text { of manuscript for } \\
\text { intellectual content }\end{array}$ \\
\hline $\begin{array}{l}\text { Hiroyuki } \\
\text { Shimada, MD, } \\
\text { PhD }\end{array}$ & $\begin{array}{l}\text { Osaka City University, } \\
\text { Japan }\end{array}$ & $\begin{array}{l}\text { Data collection, revision } \\
\text { of manuscript for } \\
\text { intellectual content }\end{array}$ \\
\hline $\begin{array}{l}\text { Mikio Shoji, MD, } \\
\text { PhD }\end{array}$ & $\begin{array}{l}\text { Hirosaki University } \\
\text { Graduate School of } \\
\text { Medicine, Japan }\end{array}$ & $\begin{array}{l}\text { Data collection, revision } \\
\text { of manuscript for } \\
\text { intellectual content }\end{array}$ \\
\hline $\begin{array}{l}\text { Kazushi Suzuki, } \\
\text { MD, PhD }\end{array}$ & $\begin{array}{l}\text { The University of Tokyo, } \\
\text { Japan }\end{array}$ & $\begin{array}{l}\text { Data collection, revision } \\
\text { of manuscript for } \\
\text { intellectual content }\end{array}$ \\
\hline $\begin{array}{l}\text { Victor L. } \\
\text { Villemagne, MD }\end{array}$ & $\begin{array}{l}\text { University of Melbourne, } \\
\text { Victoria, Australia }\end{array}$ & $\begin{array}{l}\text { Data collection, revision } \\
\text { of manuscript for } \\
\text { intellectual content }\end{array}$ \\
\hline $\begin{array}{l}\text { Chengjie Xiong, } \\
\text { PhD }\end{array}$ & $\begin{array}{l}\text { Washington University } \\
\text { School of Medicine, St. } \\
\text { Louis, MO }\end{array}$ & $\begin{array}{l}\text { Revision of manuscript } \\
\text { for intellectual content }\end{array}$ \\
\hline $\begin{array}{l}\text { Igor Yakushev, } \\
\text { MD }\end{array}$ & $\begin{array}{l}\text { German Center for } \\
\text { Neurodegenerative } \\
\text { Diseases (DZNE) Munich, } \\
\text { Germany }\end{array}$ & $\begin{array}{l}\text { Data collection, revision } \\
\text { of manuscript for } \\
\text { intellectual content }\end{array}$ \\
\hline $\begin{array}{l}\text { John C. Morris, } \\
\text { MD }\end{array}$ & $\begin{array}{l}\text { Washington University } \\
\text { School of Medicine, St. } \\
\text { Louis, MO }\end{array}$ & $\begin{array}{l}\text { Data collection, revision } \\
\text { of manuscript for } \\
\text { intellectual content }\end{array}$ \\
\hline $\begin{array}{l}\text { Randall J. } \\
\text { Bateman, MD }\end{array}$ & $\begin{array}{l}\text { Washington University } \\
\text { School of Medicine, St. } \\
\text { Louis, MO }\end{array}$ & $\begin{array}{l}\text { Data collection, revision } \\
\text { of manuscript for } \\
\text { intellectual content }\end{array}$ \\
\hline $\begin{array}{l}\text { Tammie L.S. } \\
\text { Benzinger, MD, } \\
\text { PhD }\end{array}$ & $\begin{array}{l}\text { Washington University } \\
\text { School of Medicine, St. } \\
\text { Louis, MO }\end{array}$ & $\begin{array}{l}\text { Data collection, revision } \\
\text { of manuscript for } \\
\text { intellectual content }\end{array}$ \\
\hline
\end{tabular}

Appendix 2 Coinvestigators

\begin{tabular}{lll}
\hline Name & Location & Contribution \\
\hline $\begin{array}{l}\text { Douglas } \\
\text { Galasko, MD }\end{array}$ & $\begin{array}{l}\text { University of California San } \\
\text { Diego }\end{array}$ & $\begin{array}{l}\text { Led and coordinated } \\
\text { imaging data collection } \\
\text { from site }\end{array}$ \\
\hline $\begin{array}{l}\text { Takeshi } \\
\text { Ikeuchi, MD, } \\
\text { PhD }\end{array}$ & Niigata University & $\begin{array}{l}\text { Led and coordinated } \\
\text { imaging data collection } \\
\text { from site }\end{array}$ \\
\hline $\begin{array}{l}\text { Mathias } \\
\text { Jucker, PhD }\end{array}$ & $\begin{array}{l}\text { Nerman Center for } \\
\text { (DZNE) Tübingen }\end{array}$ & $\begin{array}{l}\text { Led and coordinated } \\
\text { imaging data collection } \\
\text { from site }\end{array}$ \\
\hline $\begin{array}{l}\text { Jae-Hong } \\
\text { Lee, MD, } \\
\text { PhD }\end{array}$ & $\begin{array}{l}\text { Asan Medical Center, South } \\
\text { Korea }\end{array}$ & $\begin{array}{l}\text { Led and coordinated } \\
\text { imaging data collection } \\
\text { from site }\end{array}$ \\
\hline $\begin{array}{l}\text { Ralph } \\
\text { Martins, } \\
\text { PhD }\end{array}$ & Edith Cowan University & $\begin{array}{l}\text { Led and coordinated } \\
\text { imaging data collection } \\
\text { from site }\end{array}$ \\
\hline $\begin{array}{l}\text { Martin } \\
\text { Rossor, MD }\end{array}$ & University College London & $\begin{array}{l}\text { Coordinated imaging } \\
\text { data collection from site }\end{array}$ \\
\hline $\begin{array}{l}\text { Raquel } \\
\text { Sanchez- } \\
\text { Valle, MD, } \\
\text { PhD }\end{array}$ & Hospital Clinic of Barcelona & $\begin{array}{l}\text { Led and coordinated } \\
\text { imaging data collection } \\
\text { from site }\end{array}$ \\
\hline & & \\
\hline & &
\end{tabular}

\section{References}

1. Boyano I, Ramos A, Lopez-Alvarez J, et al. Cerebral microbleeds in advanced dementia: clinical and pathological correlates. Am J Alzheimers Dis Other Demen 2018 ; 33:362-372.

2. Iadecola C, Gottesman RF. Neurovascular and cognitive dysfunction in hypertension. Circ Res 2019;124:1025-1044.

3. Poels MM, Ikram MA, van der Lugt A, et al. Incidence of cerebral microbleeds in the general population: the Rotterdam Scan Study. Stroke 2011;42:656-661.

4. Sperling R, Salloway S, Brooks DJ, et al. Amyloid-related imaging abnormalities in patients with Alzheimer's disease treated with bapineuzumab: a retrospective analysis. Lancet Neurol 2012;11:241-249.

5. Shams S, Martola J, Granberg T, et al. Cerebral microbleeds: different prevalence, topography, and risk factors depending on dementia diagnosis: the Karolinska Imaging Dementia Study. AJNR Am J Neuroradiol 2015;36:661-666.

6. Sperling RA, Jack CR Jr, Black SE, et al. Amyloid-related imaging abnormalities in amyloid-modifying therapeutic trials: recommendations from the Alzheimer's Association Research Roundtable Workgroup. Alzheimers Dement 2011;7:367-385.

7. Ryman DC, Acosta-Baena N, Aisen PS, et al. Symptom onset in autosomal dominant Alzheimer disease: a systematic review and meta-analysis. Neurology 2014;83: 253-260.

8. Bekris LM, Yu CE, Bird TD, Tsuang DW. Genetics of Alzheimer disease. J Geriatr Psychiatry Neurol 2010;23:213-227.

9. Morris JC, Aisen PS, Bateman RJ, et al. Developing an international network for Alzheimer research: the Dominantly Inherited Alzheimer Network. Clin Investig 2012;2:975-984.

10. Bateman RJ, Xiong C, Benzinger TL, et al. Clinical and biomarker changes in dominantly inherited Alzheimer's disease. N Engl J Med 2012;367:795-804.

11. Morris JC. The Clinical Dementia Rating (CDR): current version and scoring rules. Neurology 1993;43:2412-2414.

12. Wade J, Hachinski V. Revised ischemic score for diagnosing multi-infarct dementia. J Clin Psychiatry 1986;47:437-438.

13. Storandt M, Balota DA, Aschenbrenner AJ, Morris JC. Clinical and psychological characteristics of the initial cohort of the Dominantly Inherited Alzheimer Network (DIAN). Neuropsychology 2014;28:19-29.

14. Bateman RJ, Benzinger TL, Berry S, et al. The DIAN-TU Next Generation Alzheimer's prevention trial: adaptive design and disease progression model. Alzheimers Dement 2017;13:8-19.

15. Donohue MC, Sperling RA, Salmon DP, et al. The preclinical Alzheimer cognitive composite: measuring amyloid-related decline. JAMA Neurol 2014;71:961-970.

16. Wang G, Berry S, Xiong C, et al. A novel cognitive disease progression model for clinical trials in autosomal-dominant Alzheimer's disease. Stat Med 2018;37: 3047-3055.

17. Joseph-Mathurin N, Su Y, Blazey TM, et al. Utility of perfusion PET measures to assess neuronal injury in Alzheimer's disease. Alzheimers Dement 2018;10 669-677.

18. Kantarci K, Gunter JL, Tosakulwong N, et al. Focal hemosiderin deposits and betaamyloid load in the ADNI cohort. Alzheimers Dement 2013;9(5 Suppl):S116-S123.

19. Schmidt P, Gaser C, Arsic M, et al. An automated tool for detection of FLAIRhyperintense white-matter lesions in Multiple Sclerosis. Neuroimage 2012;59: 3774-3783.

20. Benzinger TL, Blazey T, Jack CR Jr, et al. Regional variability of imaging biomarkers in autosomal dominant Alzheimer's disease. Proc Natl Acad Sci USA 2013;110: E4502-E4509.

21. Gordon BA, Blazey TM, Su Y, et al. Spatial patterns of neuroimaging biomarker change in individuals from families with autosomal dominant Alzheimer's disease: a longitudinal study. Lancet Neurol 2018;17:241-250.

22. Hosmer DW Jr, Lemeshow S. Applied Logistic Regression, 2nd ed. John Wiley \& Sons; 2004.

23. Akoudad S, Wolters FJ, Viswanathan A, et al. Association of cerebral microbleeds with cognitive decline and dementia. JAMA Neurol 2016;73:934-943.

24. Fitzmaurice GM, Laird NM, Ware JH. Applied Longitudinal Analysis, 2nd ed. John Wiley \& Sons; 2012.

25. Charidimou A, Jager HR, Werring DJ. Cerebral microbleed detection and mapping: principles, methodological aspects and rationale in vascular dementia. Exp Gerontol 2012;47:843-852.

26. Graff-Radford J, Botha H, Rabinstein AA, et al. Cerebral microbleeds: prevalence and relationship to amyloid burden. Neurology 2019;92:e253-e262.

27. Ryan NS, Bastos-Leite AJ, Rohrer JD, et al. Cerebral microbleeds in familial Alzheimer's disease. Brain 2012;135:e201; author reply e202.

28. Cairns NJ, Perrin RJ, Franklin EE, et al. Neuropathologic assessment of participants in two multi-center longitudinal observational studies: the Alzheimer Disease Neuroimaging Initiative (ADNI) and the Dominantly Inherited Alzheimer Network (DIAN). Neuropathology 2015;35:390-400.

29. Ringman JM, Monsell S, Ng DW, et al. Neuropathology of autosomal dominant Alzheimer disease in the National Alzheimer Coordinating Center Database. J Neuropathol Exp Neurol 2016;75:284-290.

30. Soosman SK, Joseph-Mathurin N, Braskie MN, et al. Widespread white matter and conduction defects in PSEN1-related spastic paraparesis. Neurobiol Aging 2016;47: 201-209.

31. Nandigam RN, Viswanathan A, Delgado P, et al. MR imaging detection of cerebral microbleeds: effect of susceptibility-weighted imaging, section thickness, and field strength. AJNR Am J Neuroradiol 2009;30:338-343. 
32. Lee S, Zimmerman ME, Narkhede A, et al. White matter hyperintensities and the mediating role of cerebral amyloid angiopathy in dominantly-inherited Alzheimer's disease. PLoS One 2018; 13:e0195838.

33. Sepehry AA, Lang D, Hsiung GY, Rauscher A. Prevalence of brain microbleeds in Alzheimer disease: a systematic review and meta-analysis on the influence of neuroimaging techniques. AJNR Am J Neuroradiol 2016;37:215-222.

34. Ryan NS, Nicholas JM, Weston PSJ, et al. Clinical phenotype and genetic associations in autosomal dominant familial Alzheimer's disease: a case series. Lancet Neurol 2016;15: 1326-1335.

35. van Rooden S, van der Grond J, van den Boom R, et al. Descriptive analysis of the Boston criteria applied to a Dutch-type cerebral amyloid angiopathy population. Stroke 2009;40:3022-3027.

36. Mann DM, Pickering-Brown SM, Takeuchi A, Iwatsubo T; members of the Familial Alzheimer's Disease Pathology Study G. Amyloid angiopathy and variability in amyloid beta deposition is determined by mutation position in presenilin-1-linked Alzheimer's disease. Am J Pathol 2001;158:2165-2175.

37. Arrighi HM, Barakos J, Barkhof F, et al. Amyloid-related imaging abnormalities-haemosiderin (ARIA-H) in patients with Alzheimer's disease treated with bapineuzumab: a historical, prospective secondary analysis. J Neurol Neurosurg Psychiatry 2016;87:106-112.

38. Yates PA, Desmond PM, Phal PM, et al. Incidence of cerebral microbleeds in preclinical Alzheimer disease. Neurology 2014;82:1266-1273.

39. Bornebroek M, Haan J, Van Duinen SG, et al. Dutch hereditary cerebral amyloid angiopathy: structural lesions and apolipoprotein E genotype. Ann Neurol 1997;41:695-698.

40. Charidimou A, Ni J, Martinez-Ramirez S, et al. Cortical superficial siderosis in memory clinic patients: further evidence for underlying cerebral amyloid angiopathy. Cerebrovasc Dis 2016;41:156-162.
41. Jeon SB, Kang DW, Cho AH, et al. Initial microbleeds at MR imaging can predict recurrent intracerebral hemorrhage. J Neurol 2007;254:508-512.

42. Lee SH, Bae HJ, Kwon SJ, et al. Cerebral microbleeds are regionally associated with intracerebral hemorrhage. Neurology 2004;62:72-76.

43. Pichler M, Vemuri P, Rabinstein AA, et al. Prevalence and natural history of superficial siderosis: a population-based study. Stroke 2017;48:3210-3214.

44. Yoshita M, Fletcher E, Harvey D, et al. Extent and distribution of white matter hyperintensities in normal aging, MCI, and AD. Neurology 2006;67: 2192-2198.

45. Lee S, Viqar F, Zimmerman ME, et al. White matter hyperintensities are a core feature of Alzheimer's disease: evidence from the Dominantly Inherited Alzheimer Network. Ann Neurol 2016;79:929-939.

46. Goos JD, Henneman WJ, Sluimer JD, et al. Incidence of cerebral microbleeds: a longitudinal study in a memory clinic population. Neurology 2010;74: 1954-1960.

47. Mann DMA, Davidson YS, Robinson AC, et al. Patterns and severity of vascular amyloid in Alzheimer's disease associated with duplications and missense mutations in APP gene, Down syndrome and sporadic Alzheimer's disease. Acta neuropathologica 2018; 136:569-587.

48. Finckh U, Kuschel C, Anagnostouli M, et al. Novel mutations and repeated findings of mutations in familial Alzheimer disease. Neurogenetics 2005;6:85-89.

49. Campion D, Flaman J-M, Brice A, et al. Mutations of the presenilin I gene in families with early-onset Alzheimer's disease. Hum Mol Genet 1995;4:2373-2377.

50. Wicklund M, Kelley B, Boeve B, et al. Familial dementia, parkinsonism, seizures and spastic paraparesis associated with the novel $\mathrm{Y} 288 \mathrm{H}$ presenilin-1 mutation. Neurology 2013;80(7 Supplement). 


\section{Neurology}

\section{Longitudinal Accumulation of Cerebral Microhemorrhages in Dominantly Inherited Alzheimer Disease}

Nelly Joseph-Mathurin, Guoqiao Wang, Kejal Kantarci, et al.

Neurology 2021;96; e1632-e1645 Published Online before print January 25, 2021

DOI 10.1212/WNL.0000000000011542

This information is current as of January 25, 2021

\section{Updated Information \&} Services

References

Citations

Subspecialty Collections

Permissions \& Licensing

Reprints including high resolution figures, can be found at: http://n.neurology.org/content/96/12/e1632.full

This article cites 47 articles, 15 of which you can access for free at: http://n.neurology.org/content/96/12/e1632.full\#ref-list-1

This article has been cited by 1 HighWire-hosted articles: http://n.neurology.org/content/96/12/e1632.full\#\#otherarticles

This article, along with others on similar topics, appears in the following collection(s):

\section{Alzheimer's disease}

http://n.neurology.org/cgi/collection/alzheimers_disease

MRI

http://n.neurology.org/cgi/collection/mri

Information about reproducing this article in parts (figures,tables) or in its entirety can be found online at:

http://www.neurology.org/about/about_the_journal\#permissions

Information about ordering reprints can be found online:

http://n.neurology.org/subscribers/advertise

Neurology ${ }^{\circledR}$ is the official journal of the American Academy of Neurology. Published continuously since 1951, it is now a weekly with 48 issues per year. Copyright Copyright ( 2021 The Author(s). Published by Wolters Kluwer Health, Inc. on behalf of the American Academy of Neurology.. All rights reserved. Print ISSN: 0028-3878. Online ISSN: 1526-632X.

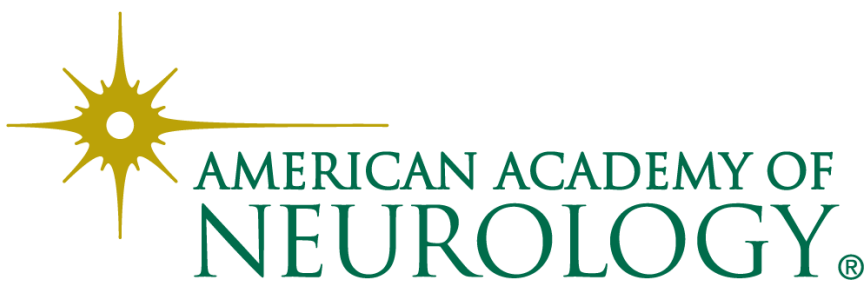

